\title{
Deletion of the Fractalkine Receptor, CX3CR1, Improves Endogenous Repair, Axon Sprouting, and Synaptogenesis after Spinal Cord Injury in Mice
}

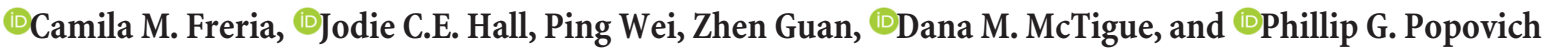 \\ Department of Neuroscience and Center for Brain and Spinal Cord Repair, Ohio State University, Wexner Medical Center, Columbus, Ohio 43210
}

Impaired signaling via CX3CR1, the fractalkine receptor, promotes recovery after traumatic spinal contusion injury in mice, a benefit achieved in part by reducing macrophage-mediated injury at the lesion epicenter. Here, we tested the hypothesis that CX3CR1-dependent changes in microglia and macrophage functions also will enhance neuroplasticity, at and several segments below the injury epicenter. New data show that in the presence of inflammatory stimuli, CX3CR1-deficient $\left(\mathrm{CX}_{3} \mathrm{CR} 1^{-1-}\right)$ microglia and macrophages adopt a reparative phenotype and increase expression of genes that encode neurotrophic and gliogenic proteins. At the lesion epicenter (midthoracic spinal cord), the microenvironment created by CX3CR1 ${ }^{-1-}$ microglia/macrophages enhances NG2 cell responses, axon sparing, and sprouting of serotonergic axons. In lumbar spinal cord, inflammatory signaling is reduced in CX3CR1 ${ }^{-l-}$ microglia. This is associated with reduced dendritic pathology and improved axonal and synaptic plasticity on ventral horn motor neurons. Together, these data indicate that CX3CR1, a microglia-specific chemokine receptor, is a novel therapeutic target for enhancing neuroplasticity and recovery after SCI. Interventions that specifically target CX3CR1 could reduce the adverse effects of inflammation and augment activity-dependent plasticity and restoration of function. Indeed, limiting CX3CR1-dependent signaling could improve rehabilitation and spinal learning.

Key words: CX3CR1; inflammation; macrophages; microglia; plasticity; spinal cord injury

\section{Significance Statement}

Published data show that genetic deletion of CX3CR1, a microglia-specific chemokine receptor, promotes recovery after traumatic spinal cord injury in mice, a benefit achieved in part by reducing macrophage-mediated injury at the lesion epicenter. Data in the current manuscript indicate that CX3CR1 deletion changes microglia and macrophage function, creating a tissue microenvironment that enhances endogenous repair and indices of neuroplasticity, at and several segments below the injury epicenter. Interventions that specifically target CX3CR1 might be used in the future to reduce the adverse effects of intraspinal inflammation and augment activity-dependent plasticity (e.g., rehabilitation) and restoration of function.

\section{Introduction}

Spinal cord injury (SCI) elicits a protracted neuroinflammatory reaction throughout the lesion epicenter and in remote regions of the brain and spinal cord (Popovich et al., 1997; Hains and Wax-

Received Sept. 9, 2016; revised Feb. 21, 2017; accepted Feb. 22, 2017.

Author contributions: C.M.F., D.M.M., and P.G.P. designed research; C.M.F., J.C.E.H., P.W., and Z.G. performed research; D.M.M. and P.G.P. contributed unpublished reagents/analytic tools; C.M.F. analyzed data; C.M.F. and P.G.P. wrote the paper.

This work was supported by Cnpq-Brazil (Science without borders) Fellowship to C.M.F. and the Ray W. Poppleton Endowment to P.G.P. We thank Dr. Alexandre L. R. Oliveira for assistance and access to the Transmission Electron Microscopy, State University of Campinas (UNICAMP), São Paulo, Brazil; Randy J. Nelson (Ohio State University) for access to the Neurolucida MBF Bioscience system; and Taryn Aubrecht for assisting with Neurolucida software.

The authors declare no competing financial interests.

Correspondence should be addressed to Dr. Phillip G. Popovich, Ohio State University, 460 West 12th Avenue, 694 Biomedical Research Tower, Columbus, $0 \mathrm{H} 43210$. E-mail: phillip.popovich@osumc.edu.

DOI:10.1523/JNEUROSCI.2841-16.2017

Copyright $\odot 2017$ the authors $\quad 0270-6474 / 17 / 373568-20 \$ 15.00 / 0$ man, 2006; Detloff et al., 2008; Hansen et al., 2013). These inflammatory cascades are dominated by microglia and monocytederived macrophages (MDMs) (Popovich and Longbrake, 2008; David and Kroner, 2011). Recent data indicate that as microglia and macrophages respond to cues in the lesion environment, stochastic activation of pattern recognition receptors (e.g., tolllike receptors) endows these cells with the ability to kill neurons and glia or enhance their growth potential (Gensel et al., 2009, 2015; Miron et al., 2013). Chemokine receptors are another class of receptors that may regulate divergent functions in microglia and MDMs after SCI.

Previously, we found that deletion of CX3CR1, a chemokine receptor that binds only to fractalkine (CX3CL1), improves functional recovery and reduces lesion pathology after SCI in mice (Donnelly et al., 2011). Improvements in locomotor function were due, in part, to reducing MDM-mediated neurotoxicity in 
CX3CR1-deficient (CX3CR1 $1^{-/-}$) mice. However, deficiencies in CX3CR1 signaling also could endow microglia, both nearby and distal to the injury epicenter, with functions that directly promote neuroplasticity and functional recovery. Indeed, data show that to achieve optimal recovery after SCI, neuroinflammation needs to be reduced at the epicenter and also in distal spinal segments (Hansen et al., 2013).

After SCI, activated microglia dominate the lesion penumbra (Popovich and Hickey, 2001; Wang et al., 2015), but these cells also exist throughout the spinal cord and into the brain (Hains and Waxman, 2006; Detloff et al., 2008; Tan et al., 2008; Hansen et al., 2013). Whether activated microglia promote repair or exacerbate injury is likely to vary as a function of time postinjury, lesion severity, and location relative to the injury epicenter. Microglia are essential for lesion containment in acute injuries (Hines et al., 2009), but their protracted activation distal to the lesion, mediated in part via neuronal chemokines, can cause neuropathic pain and impair neurological function (Zhao et al., 2007; Tan et al., 2008; Hansen et al., 2013). Such aberrant effects of microglia can be explained by their ability to directly affect the formation and removal of synapses (synaptic plasticity) and the growth and maturation of axons or dendrites (Harkema et al., 2011; Paolicelli et al., 2011; Hoshiko et al., 2012; Pont-Lezica et al., 2014; Squarzoni et al., 2014; Baalman et al., 2015). Because CX3CR1 influences microglia effects on neural circuitry and because we previously found that recovery from SCI is improved in CX3CR1 ${ }^{-/-}$mice (Donnelly et al., 2011), experiments in this report tested two distinct but interrelated hypotheses: (1) reduced inflammatory signaling in $\mathrm{CX} 3 \mathrm{CR} 1^{-1-}$ microglia and MDMs enhances endogenous repair and plasticity at/nearby the lesion epicenter; and (2) reduced inflammatory signaling in CX3CR $1^{-1-}$ microglia remote from the injury site is associated with enhanced cellular repair and anatomical plasticity, including axonal sprouting and synaptogenesis.

New data in this report show that CX3CR $1^{-/-}$microglia and MDMs augment endogenous repair, both at and distal to a SCI. At the lesion epicenter, a normally robust NG2 glial response is enhanced in CX3CR $1^{-1-}$ mice and is associated with enhanced sparing and sprouting of axons, including a subpopulation of serotonergic axons. In lumbar spinal cord, reduced inflammatory signaling in CX3CR1 $1^{-1-}$ microglia is associated with enhanced axon and synaptic plasticity and reduced dendritic pathology on spinal motor neurons.

Although damaged CNS axons do not regenerate efficiently, the CNS has the capacity to rewire connections within existing (surviving) neural circuitry, boosting spontaneous recovery and the capacity for neurorehabilitation (Bareyre et al., 2004; Courtine et al., 2008; Rosenzweig et al., 2010). Data in this report indicate that deleting CX3CR1, a chemokine receptor found exclusively on microglia and a subset of infiltrating MDMs (Cardona et al., 2006), can promote neuroprotection (sparing) and also augment plasticity in spared fibers after SCI.

\section{Materials and Methods}

Animals and surgery. Breeding pairs of CX3CR $1^{\text {GFP/GFP }}$ mice (hereafter referred to as CX3CR1 $1^{-1-}$ mice) were established from Dan Littman's original colony as described previously (Jung et al., 2000; Donnelly et al., 2011). CX3CR $1^{-1-}$ mice were generated by replacing the second exon of the $c \times 3 c r 1$ gene with the enhanced GFP reporter gene (Jung et al., 2000). Mice were backcrossed to a C57BL/6 background for $>10$ generations. Wild-type (WT) C57BL/6 mice were obtained from The Jackson Laboratory. A total of 104 male and female mice CX3CR $1^{+/+}, \mathrm{CX} 3 \mathrm{CR} 1^{+/-}$, or CX3CR $1^{-1-}$ received a moderate (75 kdyn) mid-thoracic (T9) contusion SCI (Infinite Horizons device). With the exception of images shown in Figure $1 F-I$ and the images and data in Figure $5 L-N$, all other comparisons were made between CX3CR $1^{-1-}$ and C57BL/6 WT mice. The aforementioned data were conducted as part of early experiments when CX3CR1 ${ }^{+/-}$(heterozygote) mice were considered viable "control" groups as described by other laboratories using these same mice for evaluating basic microglia physiology (Davalos et al., 2005; Cardona et al., 2006). However, as more data emerged showing that loss of a single CX3CR1 allele impairs microglia function (Rogers et al., 2011), we moved to using only CX3CR $1^{-1-}$ and C57BL/6 WT mice for quantitative comparisons. Thus, the magnitude of myelin/axon sparing (see Fig. $1 F, G$ ) and number of synapses reported in CX3CR $1^{+/-}$groups (see Fig. $5 L-N)$ likely underestimate what would have been observed had we compared CX3CR1 ${ }^{-1-}$ mice with C57BL/6 mice. All mice were anesthetized with a ketamine $(80 \mathrm{mg} / \mathrm{kg}$, i.p.)/xylazine $(10 \mathrm{mg} / \mathrm{kg}$, i.p.) mixture. Postoperatively, animals were hydrated with $2 \mathrm{ml}$ of saline (subcutaneous) and were given prophylactic antibiotic $(0.1 \mathrm{ml}$ gentamicin, s.c.) for $5 \mathrm{~d}$. Bladders were voided manually twice per day for the duration of the study. Urine $\mathrm{pH}$ was monitored weekly, and mice were observed daily for signs of infection or abnormal wound healing at the site of surgery. All housing, surgical, and postoperative care procedures were performed in accordance with the Ohio State University Institutional Animal Care and Use Committee. After 4, 14, 28 or 56 d postinjury (dpi), spinal cords were prepared for immunohistochemistry (IHC), TEM, or Golgi Cox staining. To label proliferating cells, the thymidine analog BrdU was injected ( $50 \mathrm{mg} / \mathrm{kg}$ body weight in sterile saline; i.p.; Sigma-Aldrich) into a subset of mice immediately after injury then daily for 2 weeks.

Tissue processing. For IHC, mice were killed at 0 (naive control; $n=$ 3 /group), 4, 14, 28 and $56 \mathrm{dpi}(n=5 /$ genotype). All mice were given a lethal mixture of ketamine/xylazine $(1.5 \times$ the surgical dose $)$ and then perfused intracardially with PBS $(0.1 \mathrm{M}, \mathrm{pH} 7.4)$ followed by $4 \%$ PFA in PBS. Perfused spinal cords were removed and postfixed for $2 \mathrm{~h}$ then rinsed and stored overnight in PBS. Samples were cryoprotected by immersion in 30\% sucrose for $4 \mathrm{~d}$. The $1 \mathrm{~cm}$ blocks of spinal cord tissue, centered over the injury site, were frozen on dry ice. Transverse serial (10 $\mu \mathrm{m})$ and horizontal sections $(18 \mu \mathrm{m})$ were cut on a Microm cryostat (HM 505E), collected on SuperFrost Plus slides (Thermo Fisher Scientific) then stored at $-20^{\circ} \mathrm{C}$.

For Golgi-Cox analyses, mice were perfused with PBS at 56 dpi mice ( $n=5$ /group). Lumbar spinal cords were dissected, rinsed with double distilled water, and then immersed in a 1:1 mixture of FD solution A:B (FD Rapid GolgiStain) for 2 weeks at room temperature in the dark. Spinal cords were transferred to FD Solution C and kept in the dark at $4^{\circ} \mathrm{C}$ for $48 \mathrm{~h}$. After replacing Solution C, spinal cords were frozen then embedded in disposable molds. Transverse serial sections $(150 \mu \mathrm{m})$ were cut through each block on a Microm cryostat (HM 505 E). The sections were transferred to 24 well plates onto small drops of FD Solution C, rinsed in distilled water, then immediately stained as floating sections using Golgi-staining protocol (FD Rapid GolgiStain Kit catalog \#PK401, FD NeuroTechnologies).

Additional mice were required for TEM analysis. CX3CR1 ${ }^{+/-}$and CX3CR $1^{-1-}$ mice were perfused at $56 \mathrm{dpi}(n=3 /$ group $)$ with PBS, followed by $4 \%$ PFA/2\% gluteraldehyde. The $5 \mathrm{~mm}$ segments of tissue below the lesion epicenter and lumbar enlargement were blocked in Epon-Spurr resin.

Antibodies and IHC. Antibodies used for DAB immunoperoxidase or immunofluorescence staining are listed in Table 1. For immunoperoxidase labeling, spinal cord sections were rinsed in $0.1 \mathrm{M}$ PBS and endogenous peroxidases quenched using a 4:1 solution of methanol and $30 \%$ hydrogen peroxide for $15 \mathrm{~min}$ in the dark. Sections were rinsed and blocked for nonspecific antigen binding using 4\% BSA/0.1\% Triton X-100/PBS $\left(\mathrm{BP}^{+}\right)$for $1 \mathrm{~h}$. Next, sections were incubated in primary antibody overnight in humidified chambers at $4^{\circ} \mathrm{C}$. The next day, sections were rinsed 3 times with PBS and incubated in biotinylated secondary (goat anti-rabbit 1:2000 or goat anti-chicken 1:1000 in $\mathrm{BP}^{+}$; Vector Laboratories) for $1 \mathrm{~h}$ at room temperature. Bound antibody was visualized using Elite-avidin-biotin enzyme complex (ABC; Vector Laboratories) for $1 \mathrm{~h}$ and $\mathrm{DAB}$ as a substrate (Vector Laboratories). The slides were dehydrated in $70 \%, 80 \%$, $90 \%$, and $100 \%$ ethanol and then coverslipped with Permount (Thermo 
Table 1. Antibodies used for immunohistochemistry

\begin{tabular}{llll}
\hline Antigen & Source and dilution & RRID & Vendor and catalog number \\
\hline NG2 & Rabbit 1:1000 & AB_2087605 & US Biological \#C5067-71 \\
IBA-1 & Rabbit 1:1000 & AB_839504 & Wako \#019-19741 \\
Neurofilament NF-H & Chicken 1:200 & AB_2313552 & Aves Laboratory \# NFH \\
p38MAPK & Rabbit 1:300 & AB_330713 & Cell Signaling Technology \#9212 \\
Biotinylated BrdU & Sheep 1:200 & AB_302944 & Abcam \#ab2284 \\
5-HT & Rabbit 1:2000 & AB_477522 & Sigma-Aldrich \#S5545 \\
GFAP & Rabbit 1:1000 & AB_10013382 & Dako\#ZO334 \\
Synapsin & Rabbit 1:1000 & AB_11042000 & Synaptic Systems \#106-103 \\
VGlut1 & Guinea pig 1:1000 & AB_887878 & Synaptic Systems \#135-304 \\
Homer-1 & Rabbit 1:400 & AB_887730 & Synaptic Systems \#160-003 \\
VGlut2 & Guinea pig 1:5000 & AB_887884 & Synaptic Systems \#135-404 \\
GAD1-GAD67 & Rabbit 1:1000 & AB_2107718 & Synaptic Systems \#198-013 \\
VGAT & Guinea pig 1:1000 & AB_887873 & Synaptic Systems \#131-004 \\
Gephyrin & Rabbit 1:300 & AB_2619834 & Synaptic Systems \#147-008 \\
\hline
\end{tabular}

Fisher Scientific). For BrdU IHC, sections were treated with $2 \mathrm{~N} \mathrm{HCl}$ at $37^{\circ} \mathrm{C}$ for $25 \mathrm{~min}$ to denature DNA before applying primary antibody. For DAB double-labeling, sections were overlaid with blocking solution (4\% $\mathrm{BSA}^{+} \mathrm{BP}^{+}$) for $1 \mathrm{~h}$ before applying the second primary antibody. Eriochrome cyanine was used to stain and distinguish intact myelin from gray matter and lesioned tissue as described previously (Kigerl et al., 2006). For immunofluorescent labeling, spinal cord sections were rinsed, blocked, and incubated in primary antibody as above. The next day, sections were rinsed 3 times with PBS and incubated in secondary antibody (1:1000 AlexaFluor-546, -33, -88; Invitrogen). After rinsing, slides were coverslipped with Immu-Mount (Thermo Scientific).

Quantifying IHC labeling: proportional area. To quantify proportional area (see Figs. 1, 4, 8) of neurofilament, 5-HT, p38MAPK, and IBA-1 images were digitized using a Zeiss Axioplan 2 Imaging microscope (Carl Zeiss) and then analyzed using an MCID Elite image analysis system (Imaging Research). Proportional area was determined by dividing the area occupied by immunoreactive cells or axons within a sample area or region of interest (ROI) by the total area of the ROI. For microglia (IBA-1; see Fig. 8), eight transverse sections spanning the L2-L3 and L4-L5 spinal segments were quantified. For p38MAPK (see Fig. 8), two transverse sections $\sim 6 \mathrm{~mm}$ from the epicenter were analyzed. Both were quantified at $56 \mathrm{dpi}$.

Number of neurofilament (NF)-positive axon profiles at lesion site. Sections stained with anti-NF antibodies were digitized using a Zeiss Axioplan 2 Imaging microscope (Carl Zeiss). ImageJ was used to count axon profiles within an ROI spanning the area between spared myelinated axons and more centrally located regions of the spinal cord containing remnants of gray matter or connective tissue. Thousands of axon profiles were detected; however, only those achieving a continuous length of at least $4 \mu \mathrm{m}$ length were counted (see Fig. $1 J$ ).

NG2 and NF. Fluorescent images were captured on a FluoView FV1000 laser scanning confocal microscope (Olympus). For each animal, $15 \mathrm{im}-$ ages $(20 \times)$ were captured from horizontal sections at the level of the central canal. Horizontal images were stitched together using Adobe Photoshop (version CS6) to create montages (see Fig. $3 A, B$ ). MetaMorph Image Analysis software (version 6.1) was used to quantify the proportional area of NG2 within an ROI $\left(690 \mu \mathrm{m}^{2}\right)$ spanning the rostralcaudal interface centered on the lesion epicenter (see Fig. 3C). Horizontal sections double-labeled for NG2/NF were used to quantify the percentage NG2/NF colocalization (see Fig. 3I). Images of NG2 and NF were each given a threshold and the overlapping regions for NG2 and NF measured using MetaMorph Image Analysis software (version 6.1) within a square ROI $\left(302 \mu \mathrm{m}^{2}\right)$.

$\mathrm{NG} 2$ cell proliferation. $\mathrm{NG}^{+} / \mathrm{BrdU}^{+}$double-labeled cells were counted in the epicenter at $56 \mathrm{dpi}$ in three sections spanning the dorsal-ventral axis $(360,630$, and $900 \mu \mathrm{m}$ from the dorsal spinal surface) of the spinal cord on 1-mm-long horizontal sections (see Fig. $3 F$ ). Only cells with a well-defined border surrounding an identified nucleus were counted. $\mathrm{NG} 2{ }^{+}$macrophages or pericytes were excluded based on morphological criteria (McTigue et al., 2001).
5- $\mathrm{HT}^{+}$axons. Horizontal montages ( $\sim 6 \mathrm{~mm}$ long) of the spinal cord were generated with $20 \times$ images from three horizontal sections spanning the dorsoventral axis $(360,630$, and $900 \mu \mathrm{m}$ from the dorsal spinal surface) of the spinal cord gray matter. A box was drawn within an ROI at and rostral to the lesion epicenter at $56 \mathrm{dpi}$. ImageJ software (version 1.48d, National Institutes of Health) was used to quantify $5-\mathrm{HT}^{+}$axon density within these areas (see Fig. $4 E$ ). Time-dependent changes in $5-\mathrm{HT}^{+}$axon profiles were quantified at 4, 14, 28, and $56 \mathrm{dpi}$ and were expressed relative to identical areas in naive sections (see Fig. $4 H$ ). $5-\mathrm{HT}^{+}$axon profiles within the ventral horn (lamina IX) were quantified at 56 dpi in each of two cross-sections from L3 and L4 lumbar spinal cord (see Fig. $4 F, G$ ). A $z$ stack of each section was acquired at high-power $\left(63 \times\right.$ magnification/1.40 oil DIC); then $5-\mathrm{HT}^{+}$profiles were counted within an ROI containing at least two motor neurons (see Fig. 4I,J). A binary image was generated from each fluorescent $z$ stack, and only $5-\mathrm{HT}^{+}$profiles $>0.5 \mu \mathrm{m}$ in length were counted (see Fig. $4 \mathrm{~K}$ ).

Synaptic puncta. Synaptic puncta were analyzed using the Puncta Analyzer plug in developed for ImageJ 1.26 (kindly provided by Dr. Cagla Eroglu). Fluorescent $z$ stack images were taken using an Olympus FluoView FV1000 and Leica TCS SP8 laser scanning confocal microscope. Measurements were performed on 2 or 3 images from L3 and L4, where most neurons innervating muscles responsible for locomotion are located. For synapsin (presynaptic receptor), images were captured at $60 \times$ ( $Z$ intervals $0.25 \mu \mathrm{m} / 10-\mu \mathrm{m}$-thick section) and analyses performed on $\sim 36-40$ images/sample. Within ventral horn lamina IX, a square ROI was drawn $\left(0.029 \mathrm{~mm}^{2}\right)$ and all synaptic puncta within the ROI counted (see Fig. $5 K$ ).

Excitatory and inhibitory synaptic puncta. Glutamic acid decarboxylase (GAD) 1-GAD67 synaptic punta were measured on images taken at $40 \times 1$ 1.8 oil magnification on DIC using $Z$ intervals of $0.30 \mu \mathrm{m}$ in a $10-\mu \mathrm{m}-$ thick section (see Fig. 6D). For VGAT and gephyrin measurements, fluorescent images were taken at $Z$ intervals of $0.35 \mu \mathrm{m}$ on $10-\mu \mathrm{m}$-thick sections (see Fig. $6 N$ ). VGlut1 is highly expressed in lamina VII and VGlut2 in lamina IX of the spinal cord. Combined labeling of these two presynaptic excitatory receptors allows for quantification of all excitatory synaptic contacts. We labeled postsynaptic receptors with Homer-1. Fluorescent $z$ stack images were captured at $40 \times / 1.8$ oil on DIC at $Z$ intervals of $0.30 \mu \mathrm{m}$ over $10-\mu \mathrm{m}$-thick sections. Within lamina VII, a square $(0.05$ $\mathrm{mm}^{2}$ ) was drawn and the number of colocalized presynaptic and postsynaptic receptors VGLUT1 and Homer-1 were counted within this area (see Fig. 7I). The number of colocalized puncta for presynaptic and postsynaptic receptors VGlut2 and Homer-1 was measured on images taken at $40 \times / 2.0$ oil magnification and within lamina IX (see Fig. $7 R$ ).

$T E M$. Ultrathin transverse sections $(50-70 \mathrm{~nm})$ were cut from blocks of spinal cord on an ultramicrotome (Ultracut MZ6; Leica). Sections were placed on formvar-coated copper grids and then contrasted with uranyl acetate and lead citrate. The samples were examined under a Tecnai Spirit G2 Bio-twin (Fei) transmission electron microscope operating at $80 \mathrm{kV}$. To measure synaptic covering, neurons with large cell bodies ( $>35 \mu \mathrm{m}$ diameter) in the ventral motor pool and cut in the nuclear plane were identified as $\alpha$ motor neurons by the presence of C-type nerve terminals. The surface of the cells was then sequentially digitalized at a magnification of $\times 11.000$. Images were mounted together using Corel Draw X5 Graphics software, and the total perimeter of neurons $(\mu \mathrm{m})$ was measured. Synaptic terminals apposing motoneuron somata were identified and their length of apposition was measured using Image Toll software (version 3.0, University of Texas Health Center, Santo Antonio, TX) and then expressed as a percentage of synaptic coverage as described previously (Freria et al., 2012).

Neuronal dendrites and spines (from Golgi-Cox stain). Forty motor neurons located in the lumbar (L2-L5) spinal cord ventral horn in $\mathrm{CX} 3 \mathrm{CR} 1^{+/+}$and $\mathrm{CX} 3 \mathrm{CR} 1^{-/-}$mice were measured. From each neuron, the number of dendrites, perimeter of neuron cell body, longest dendrite, number of dendritic spines, and dendritic spine length were counted using Zeiss Axio Image M2 Microscope and Neurolucida neuron tracing software (MBF Bioscience; RRID: SCR_001775). Two dendrites per neuron, at least $20 \mu \mathrm{m}$ away from the soma, were randomly chosen, and the length of dendritic spines was measured along a $50 \mu \mathrm{m}$ length of the dendrite shaft. Neurons were considered "beaded" if they had at least 
three varicosities along the same dendrite (see Fig. 10). Thirty neurons from each group were counted. In beaded neurons, one dendrite per neuron, at least $10 \mu \mathrm{m}$ away from the soma, was randomly chosen, and numbers of beaded structures along at least $100 \mu \mathrm{m}$ length of dendrite were counted. Data are expressed as number of beaded neurons (normalized to dendrite length). In addition, the area of each varicosity on the same dendrite was examined, and the result was represented as area of varicosity $\left(\mu \mathrm{m}^{2}\right)$. To measure the geometric characteristic of dendritic spines, 20 motor neurons located in the ventral horn of lumbar spinal cord (L2-L5) were analyzed in each group at $56 \mathrm{dpi}$. One dendrite at least $10 \mu \mathrm{m}$ away from the soma was randomly chosen, and the length and width of individual dendritic spines along a $50 \mu \mathrm{m}$ length of dendrite were measured. Spines were characterized as "mushroom" (mature) when they were $>0.6 \mu \mathrm{m}$ in width, "filopodial (Filo)" (immature) when they were $>2 \mu \mathrm{m}$ in length, or "thin" (immature) when they had a length to width ratio $>3 \mu \mathrm{m}$.

Primary cortical neuron cultures. Cortical neurons were isolated from neonatal mice at E12.5-E13. Using aseptic techniques, entire forebrains were removed and placed in cold Hibernate $\mathrm{HE} \mathrm{Ca} 2+$ free (Invitrogen, A12476-01). The meninges were removed and brain pieces minced. Tissues were collected into sterile tubes and then incubated in Hibernate $\left(\mathrm{Ca}^{2+}\right.$ free), papain (Worthington \#3119- $20 \mathrm{U} / \mathrm{ml}$ ) and DNase ( $\sigma$ D5025- 5 $\mathrm{mg} / \mathrm{ml}$ ) at $37^{\circ} \mathrm{C}$ for $30 \mathrm{~min}$. Tissue was triturated through polished glass pipettes with progressively smaller-tip diameters. Debris was removed by allowing the pieces to settle between trituration steps. After trituration, cells were suspended in fresh media [Neurobasal A (Invitrogen) with 2\% B27 supplement (Invitrogen), 1\% Glutamax, and gentomicin 1:2000], and live cells were counted on a hemocytometer using trypan blue exclusion method. Cells were grown at $37^{\circ} \mathrm{C} / 5 \% \mathrm{CO}_{2}$ in poly-D-lysine $(\sigma$ P7886 mk30K-70K; $0.25 \mathrm{mg} / \mathrm{ml}$ ) and laminin (Sigma, L2020) $5 \mu \mathrm{g} / \mathrm{ml}-$ coated plastic culture plates seeded with glass coverslips. Cells were plated at $8 \times 10^{4} \mathrm{cells} / \mathrm{cm}^{2}$ and used $14 \mathrm{~d}$ after initial plating. For measuring varicosities along dendrites of cultured neurons, four pictures randomly chosen from 2 different coverslips were taken at $40 \times$ using a Zeiss Apotome microscope equipped with Axio camera MRM. Varicosities were counted on the longest process extending from each neuron. Varicosities were counted on eight neurons from each experimental group. Data are expressed as number of varicosities per dendrite length.

Primary microglia cultures. Using aseptic technique, the forebrain and brainstem were removed from postnatal mouse pups P1-P2 (CX3CR1 $1^{+/+}$ and $\left.\mathrm{CX} 3 \mathrm{CR} 1^{-1-}\right)$ and were placed in cold $10 \%$ glucose. Using fine forceps, meninges were removed and brains were incubated in trypsin EDTA $0.05 \%$ in a sterile tube for $20 \mathrm{~min}$. Tissue was triturated through a $1 \mathrm{ml}$ pipette; then cells were suspended in fresh media (DMEM-F12 Invitrogen 09045; 1\% REPES Invitrogen Sigma H-0887; 10\% FBS and gentomicin 1:2000 Invitrogen 15710-064). Live cells were counted on a hemocytometer using the trypan blue exclusion method and placed into $150 \mathrm{~mm} \times 25 \mathrm{~mm}$ plates (Corning 430599). After 2.5 weeks, microglia were collected from the bottom of the astrocyte layer using $0.25 \%$ trypsin EDTA (Saura et al., 2003), then were reseeded into plate inserts (Millipore $0.4 \mu \mathrm{m}$ pore) at $3.5 \times 10^{4}$ cells $/ \mathrm{cm}^{2}$. For analysis of microgliaconditioned media (MCM), $5 \times 10^{5}$ cells were reseeded in fresh media (Neurobasal A; 2\% B27 supplement, 1\% Glutamax, and gentomicin 1:2000) onto 24-well plastic culture plates. MCM was collected after $24 \mathrm{~h}$ and diluted 1:1 with fresh media before adding MCM to neurons. After $24 \mathrm{~h}$, coverslips of neurons cocultured with microglia or MCM were fixed using 2\% PFA for $20 \mathrm{~min}$, followed by a PBS wash. Blocking solution (100 $\mu \mathrm{l}$ of 0.1 м PBS/ $10 \% \mathrm{FBS} / 0.1 \%$ Triton X-100) was applied for $1 \mathrm{~h}$ at room temperature, followed by primary antibody $\beta$ tubulin III (1:1000 in blocking solution) overnight at $4^{\circ} \mathrm{C}$. Primary antibody was aspirated, and cells were washed in PBS. Secondary antibody anti-rabbit was applied 1:1000 for $1 \mathrm{~h}$ at room temperature.

Bone marrow-derived macrophages. Previously, we showed that bone marrow-derived macrophages predict many of the phenotypic, molecular, and functional characteristics of the monocyte-derived macrophages that infiltrate the injured spinal cord (Longbrake et al., 2007; Kigerl et al., 2009). Accordingly, bone marrow-derived macrophages were generated from bilateral femurs and tibias of adult C57BL/6 and CX3CR1 ${ }^{-1-}$ mice
Table 2. Primer sequences for real time RT-PCR

\begin{tabular}{lll}
\hline Mus gene & Forward primer $\left(5^{\prime}-3^{\prime}\right)$ & Reverse primer $\left(5^{\prime}-3^{\prime}\right)$ \\
\hline NT3 & TCC-TCA-GCC-ATT-GAC-ATT-CG & GAT-CTC-CCC-CAG-CAC-TGT-GA \\
BDNF & TAT-TAG-CGA-GTG-GGT-CAC-AGC-G & TTC-GGC-ATT-GCG-AGT-TCC-AG \\
FGF2 & GGC-TGC-TGG-CTT-CTA-AGT-GT & ACT-GGA-GTA-TTT-CCG-TGA-CCG \\
IGF1 & TGA-CAT-GCC-CAA-GAC-TCA-GAA-G & GCG-GTG-ATG-TGG-CAT-TTT-C \\
MMP9 & TGG-AAC-TCA-CAC-GAC-ATC-TTC-C & CGG-TTG-AAG-CAA-AGA-AGG-AGC \\
TGF $\beta 1$ & ATT-CAG-CGC-TCA-CTG-CTC-TTG & GCT-GAT-CCC-GTT-GAT-TTC-CA \\
18S & TTC-GGA-ACT-GAG-GCC-ATG-AT & TTT-CGC-TCT-GGT-CCG-TCT-TG \\
\hline
\end{tabular}

(see Fig. 2) as described previously (Longbrake et al., 2007; Kigerl et al., 2009). Briefly, marrow cores were flushed then differentiated into macrophages as described previously (Longbrake et al., 2007; Kigerl et al., 2009). Macrophages $\left(5 \times 10^{4}\right.$ cells $\left./ \mathrm{cm}^{2}\right)$ were seeded onto sterile glass coverslips and then were incubated at $37^{\circ} \mathrm{C} / 5 \% \mathrm{CO}_{2}$ for $12 \mathrm{~h}$, after which macrophages were stimulated with media only (control) or inflammatory stimuli: LPS (100 ng/ml; Sigma-Aldrich) plus IFN $\gamma(20 \mathrm{ng} / \mathrm{ml}$; eBioscience) for $24 \mathrm{~h}$. Twenty-four hours later, cells were either fixed with $4 \%$ PFA or media was removed from the culture and Trizol (Invitrogen) was added to isolate RNA. Fixed cells were stained by overlaying cells with blocking solution for $1 \mathrm{~h}$; then AlexaFluor Phalloidin 546 (1:200; catalog \#A22283 Invitrogen) was applied for $2 \mathrm{~h}$ at room temperature. After rinsing, all coverslips were placed onto slides with Immu-Mount. Fluorescence images were taken at $20 \times$ using a Zeiss Apotome microscope equipped with a Zeiss Axio camera MRM. Cell area and perimeter were assessed using MCID Elite image analysis system. Form factor (FF) was calculated using the following formula: $\mathrm{FF}=4 \pi$ area/(perimeter) ${ }^{2}$ according to (Wilms et al., 1997). The FF of a perfect circle is equal to 1; morphologies that deviate from a perfect circular have a FF $<1$. Based on FF, we identified macrophages as bipolar, unipolar, elongated, flat or round.

For PCR analysis and subsequent analysis by real-time PCR, RNA was isolated according to the manufacturer's protocol and then treated with DNase I $(1 \mu \mathrm{g} / \mu \mathrm{l})$ to eliminate genomic DNA contamination (Invitrogen); $1-2 \mu \mathrm{g}$ of DNase-treated RNA was primed with random hexamers ( $1 \mu \mathrm{M}$, Applied Biosystems) and reverse transcribed using Super-Script II reverse transcriptase (Applied Biosystems). Primer pairs were designed using ABI Prism Primer Express 2.0. Primer sequence specificity was confirmed by performing BLAST analysis for highly similar sequences against known sequence databases. Forward and reverse primer sequences for each gene are listed in Table 2. RNA profiles were analyzed using primers specific to the gene of interest and SYBR Green master mix (Applied Biosystems). All PCR was performed using an Applied Biosystems 7300 system. Melting point analyses were performed for each reaction to confirm single amplified products. Gene expression was extrapolated from standard curves generated concurrently for each gene using a control cDNA dilution series. Expression was normalized to $18 \mathrm{~S}$ for each sample. Data were calculated using the $\Delta \Delta \mathrm{Ct}$ method (Schmittgen and Livak, 2008) and expressed as fold change from control macrophages cells (gene/18S ratio for control samples/unstimulated macrophages). Data in Figure 2 are representative of one of three independents experiments.

Data analysis. All investigators involved in data acquisition or analysis were blind to group designation or experimental manipulations. Blinding was accomplished by assigning animals a unique identification (ID) number before injury. These unique numbers were maintained on all samples throughout the period of assessment. An individual that was not involved with data analysis or acquisition made all ID assignments. Data were analyzed using GraphPad Prism 5 and are presented as mean \pm SEM. Neurofilament, RT-PCR data, NG2 cell counts, NG2 proportional area, number of $5-\mathrm{HT}^{+}$axons, synaptic covering, inhibitory and excitatory synapses, IBA-1 proportional area, axonal varicosities, and dendritic spines were analyzed by Student's (unpaired) two-tailed $t$ test. All other data, including macrophage FF (see Fig. 2E, F), 5-HT density (see Fig. $4 E, H$ ), number of puncta synapses (see Fig. $5 K$ ), IBA-1 PA (see Fig. $8 E$ ), and dendritic spines morphology (see Fig. $9 L-N$ ), were analyzed by two-way ANOVA with Bonferroni's post hoc test. 

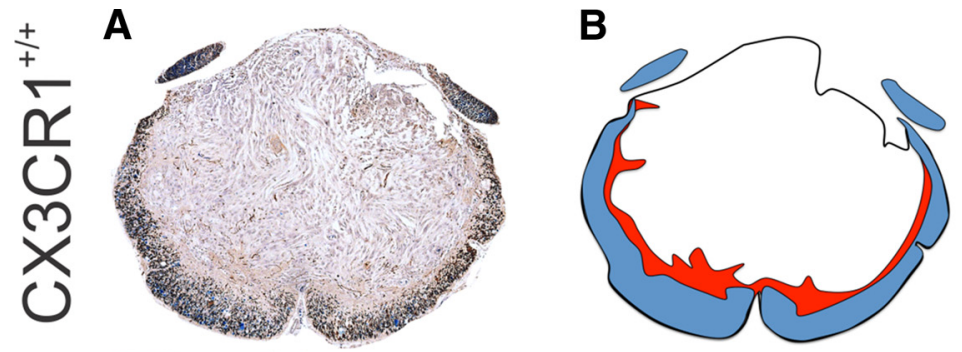

C
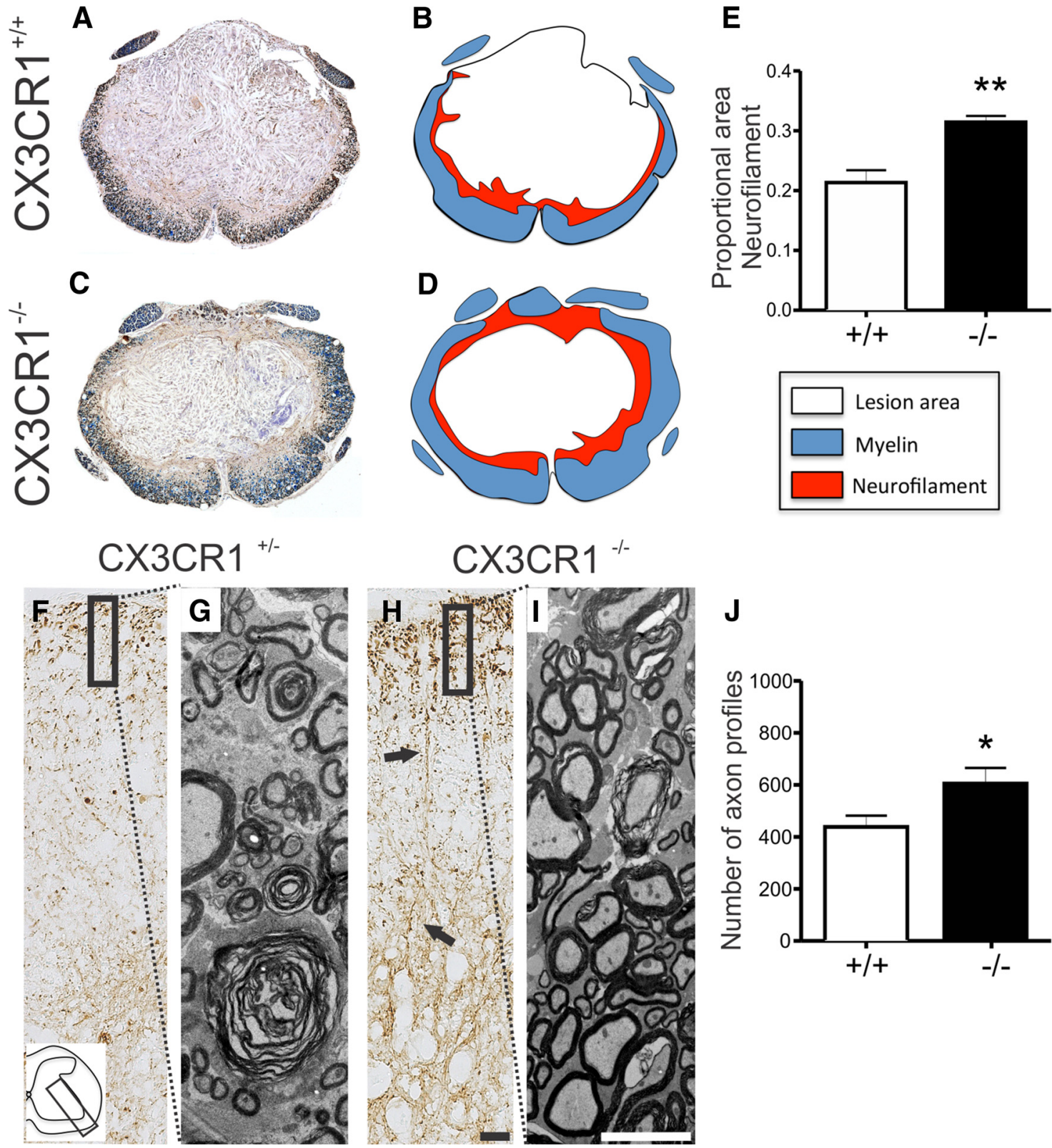

$\mathrm{CX} 3 \mathrm{CR} 1^{-1-}$

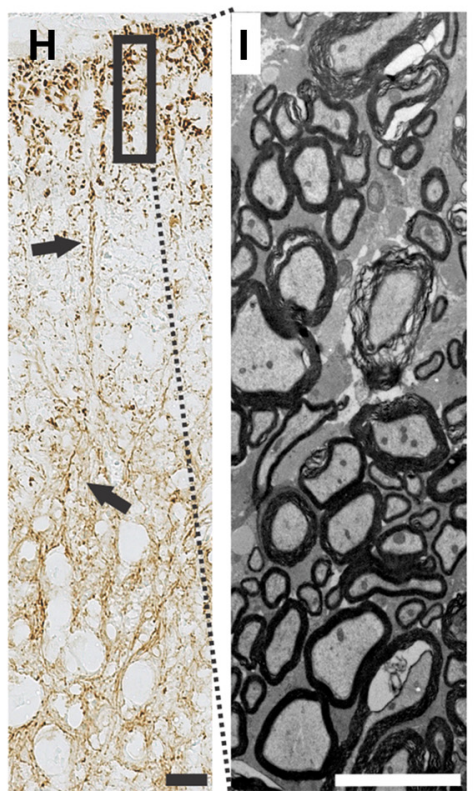

$\mathbf{J}$

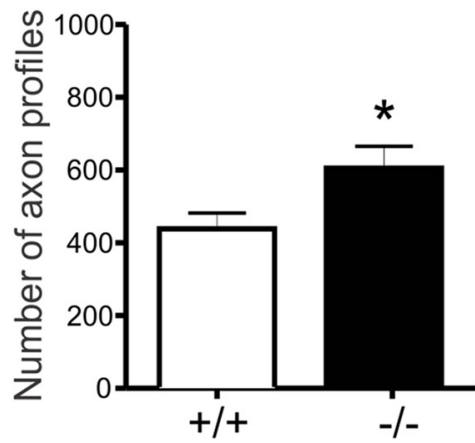

Figure 1. Impaired CX3CR1 signaling confers neuroprotection (myelin and axons) and enhances endogenous repair after SCl. A-D, Eriochrome cyanine (EC, blue) and neurofilament (NF200, brown) labeling in $\mathrm{CX} 3 \mathrm{CR} 1^{+/+}$and $\mathrm{CX} 3 \mathrm{CR} 1^{-/-}$mice at $56 \mathrm{dpi}$. Light microscopic images from representative mice $(A, C)$ and schematic maps of those images illustrate the mean differences in spared myelin (EC) and axon (NF ${ }^{+}$immunoreactivity) area. $\boldsymbol{E}$, Greater NF labeling was observed in $\mathrm{CX3CR} 1^{-1-}$ mice at 8 weeks after injury. $\boldsymbol{F}$, $\boldsymbol{H}$, Representative images of NF labeling in CX3CR1 ${ }^{-1-}(\boldsymbol{F})$ and $\mathrm{CX3CR} 1^{+/-}$mice $\left.\boldsymbol{H}\right) \sim 0.8 \mathrm{~mm}$ caudal to the lesion site. $\boldsymbol{G}, \boldsymbol{I}$, Electron microscopic images of sections cut from tissue blocks adjacent to those used in $\boldsymbol{F}, \boldsymbol{H}$ confirm genotype-dependent differences in axon sparing $\left(\boldsymbol{G}, \mathrm{CX} 3 \mathrm{CR} 1^{+-} ; \boldsymbol{I}, \mathrm{CX} 3 \mathrm{CR} 1^{-I-}\right) . \boldsymbol{F}, \boldsymbol{H}$, Boxed regions represent the regions of spared white matter from which images in $\mathbf{G}, \boldsymbol{I}$ were captured. $\boldsymbol{J}$, Numbers of $\mathrm{NF}^{+}$axon profiles ("streamers") were measured (arrows in $\boldsymbol{H} ; \sim 4-10 \mu \mathrm{m}$ in length) within regions between spared myelinated axons and central gray matter in the lesion core. $\mathrm{NF}^{+}$ axon profiles were increased significantly in $\mathrm{CX} 3 \mathrm{CR} 1{ }^{-1-}$ spinal cord sections. Graphs are representative of single independent experiments $\left(n=5+/+\right.$ and $n=6-/-$ mice/group). ${ }^{*} p<0.05$ (Student's unpaired two-tailed $t$ test). ${ }^{* *} p<0.01$ (Student's unpaired two-tailed $t$ test). Scale bars: $\boldsymbol{H}, 5 \mu \mathrm{m} ; \boldsymbol{I}, 50 \mu \mathrm{m}$. Data are mean \pm SEM.

\section{Results}

After experimental spinal contusion injury, CX3CR1 expression is dynamically regulated in CNS myeloid cells (microglia and MDMs) and abolishing CX3CR1 signaling in these cells improves functional recovery with significant neuroprotection evident at the injury site for at least 4-6 weeks after injury (Donnelly et al., 2011). Extending previously published data from our laboratory, new data in Figure 1 show significant protection of myelinated axons within the injured spinal cord of CX3CR1-deficient $\left(\mathrm{CX} 3 \mathrm{CR}^{-/-}\right)$mice at 8 weeks after injury (Fig. $\left.1 \mathrm{~A}, \mathrm{H}, \mathrm{I}\right)$. Also notable in these lesions were numerous thin axonal sprouts $(\sim 4-10 \mu \mathrm{m})$ that span the area between spared axons in the ventrolateral white matter and more centrally located regions of "spared" gray matter (Fig. $1 F, H, J)$. Axonal "sprouts" were more prevalent in CX3CR $1^{-1-}$ mice (Fig. $1 J$ ) and could indicate the presence of a lesion environment that is less toxic and/or more supportive of cell growth and migration.

\section{Inflammatory stimuli elicit a "tissue-repair" phenotype in CX3CR1-deficient macrophages}

Intracellular signaling networks control cell protrusion, adhesion, and tension, which in turn affects nuclear organization, 
chromatin condensation, and histone modification; all can impact the genetic programs that influence macrophage phenotype and function (Bakal et al., 2007; McWhorter et al., 2013). To determine whether CX3CR1 deficiency induces morphological and molecular changes in CNS myeloid cells, which might predict functions that enhance cell (axon) growth and/or limit neurotoxicity, macrophages were prepared from WT and CX3CR $1^{-1-}$ mice. Cells were stimulated with IFN $\gamma+$ LPS to induce an inflammatory "M1" phenotype, one that causes neurotoxicity and axonal die-back in models of SCI (Popovich et al., 1999; Horn et al., 2008; Busch et al., 2009). Unstimulated (M0) macrophages served as controls. Resting or stimulation-induced changes in cell morphology and gene expression were compared between genotypes.

The area and perimeter of macrophages were used to calculate FF (Wilms et al., 1997). FF is a morphometric measure of circularity; a perfect circle has $\mathrm{FF}=1$, whereas a line has $\mathrm{FF}=0$. Phalloidin staining was used as it reveals actin-rich filipodial extensions from the soma of both WT and CX3CR $1^{-1-}$ macrophages (Fig. 2A-D). Under control (M0) conditions, $85 \%$ of WT and CX3CR $1^{-1-}$ macrophages exhibited bipolar or unipolar morphologies at similar frequencies (Fig. 2E). When activated with inflammatory (M1) stimuli, most WT macrophages adopted an elongated or flat morphology with few filipodia (Fig. $2 F$ ). Conversely, inflammatory stimuli failed to elicit this "activated" morphology in CX3CR $1^{-/-}$macrophages; most remained smaller with a unipolar morphology and FF similar to that of unstimulated macrophages.

Such distinct morphological differences are likely associated with unique gene expression profiles. We evaluated resting and inflammatory-induced changes in TGF $\beta 1, I G F 1, F G F 2, B D N F$, $N T 3$, and MMP9. These genes are released by macrophages and have potent effects on axon growth (Zhou and Shine, 2003), NG2 cell proliferation and differentiation (McTigue et al., 1998; Wu et al., 2010; Liu and Shubayev, 2011; Wennström et al., 2014), and tissue remodeling (Lu et al., 2011). At rest (no stimulation), baseline gene expression was similar in CX3CR $1^{-1-}$ and WT macrophages (data not shown). However, in response to inflammatory stimuli, marked changes in gene expression were noted for a subset of genes. Notably, TGF 1 , IGF1, and FGF2 mRNA expression increased significantly only in $\mathrm{CX} 3 \mathrm{CR} 1^{-1-}$ macrophages (Fig. 2G-I). Other genes (BDNF, NT3, and MMP9) were largely unaffected by the absence of CX3CR1 (Fig. 2J-L). Based on previously published data (Donnelly et al., 2011) and data in Figure 2, we can conclude that inflammatory stimuli fail to elicit a neurotoxic phenotype in $\mathrm{CX} 3 \mathrm{CR} 1^{-1-}$ macrophages. Instead, deletion of CX3CR1 enhances the neurotrophic and gliogenic potential of intraspinal macrophages.

\section{CX3CR1-deficient macrophages create an environment that supports NG2 glia and the growth or stability of axons}

After SCI, NG2 glia increase at the interface between the macrophagerich lesion core and adjacent spared tissue (Lytle et al., 2006, 2009; Tripathi and McTigue, 2007; Wu et al., 2010). Based on data in Figures 1 and 2, we predicted that the altered inflammatory milieu created by $\mathrm{CX} 3 \mathrm{CR} 1^{-/-}$macrophages would affect the endogenous NG2 glia response after SCI.

After SCI, the density of NG2 glia was significantly greater across the rostrocaudal extent of the chronic ( $56 \mathrm{dpi}$ ) contusion lesion in CX3CR1 ${ }^{-1-}$ mice compared with WT mice (Fig. 3A-C). To determine whether this develops as a result of enhanced NG2 cell proliferation at a time coinciding with the onset and peak of intraspinal macrophage activation, mice were pulsed with BrdU daily for 2 weeks starting immediately after SCI. NG2 cell proliferation increased significantly in $\mathrm{CX} 3 \mathrm{CR} 1^{-/-}$mice relative to WT mice; total number of $\mathrm{NG}^{+} / \mathrm{BrdU}^{+}$cells increased $\sim 20 \%$ at the lesion border in CX3CR $1^{-/-}$mice (Fig. $\left.3 D-F\right)$.

Although NG2 proteoglycans can inhibit growth and synaptic transmission in some axons (Tan et al., 2006; Petrosyan et al., 2013), $\mathrm{NG}^{+}$glia also can stabilize or limit die-back of injured axons and can serve as substrates for growing axons, especially serotonergic (5-HT) axons (McTigue et al., 2006; Busch et al., 2010). Double-labeling for NG2 and axons (NF) revealed a marked increase in colocalization between NG2 glia and axons at the lesion border (Fig. 3G-K). Consistent with previous reports from our group (McTigue et al., 2006), NG2 cells could be seen wrapping or closely apposed to axons (Fig. $3 \mathrm{~J}, \mathrm{~K}$ ).

\section{Enhanced 5-HT axon growth at and distal to the lesion epicenter in CX3CR1 ${ }^{-1-}$ mice}

When injured, serotonergic $\left(5-\mathrm{HT}^{+}\right)$axons have an unusual propensity to grow new branches from the proximal regions of their injured axons (Jacobs and Fornal, 1997; Schmidt and Jordan, 2000; Hawthorne et al., 2011); however, recent data indicate that injured 5- $\mathrm{HT}^{+}$axons exhibit true regenerative growth with little contribution from local sprouting (Jin et al., 2016). Here, $5-\mathrm{HT}^{+}$axons were labeled then quantified in lumbar spinal cord as a function of time postinjury. Overall, the density of 5-HT axons was then analyzed via two-way ANOVA with genotype and location (rosral/epicenter) as independent variables. There were significant main effects of both genotype $\left(F_{(1,16)}=13.85, p=\right.$ $0.0019)$ and location relative to the site of injury $\left(F_{(1,16)}=9.24\right.$, $p=0.0078$; Figure $4 A-E)$. When evaluated over time relative to naive genotype-matched spinal cords, $5-\mathrm{HT}^{+}$axons were reduced at all times in both groups (Fig. 4H). However, by $56 \mathrm{dpi}$, the density of $5-\mathrm{HT}^{+}$axons increased $>30 \%$ in $\mathrm{CX} 3 \mathrm{CR} 1^{-1-}$ mice, especially in the ventral horn (Fig. $4 F-H$ ). A closer look at these axons revealed obvious differences in both the length and morphology of the $5-\mathrm{HT}^{+}$fibers with more and longer $5-\mathrm{HT}^{+}$ profiles present in CX3CR1 $1^{-/-}$spinal cords (Fig. $4 I-K$ ). Based on the repopulation kinetics of 5-HT labeling and the known plasticity and regenerative potential of $5-\mathrm{HT}^{+}$axons (Saruhashi et al., 1996; Müllner et al., 2008; Takeoka et al., 2009; Hawthorne et al., 2011; Jin et al., 2016), these are likely "new" regenerated axons.

\section{Enhanced synaptic plasticity in lumbar spinal cord of CX3CR1 $1^{-/-}$mice}

We next tested whether the increase in axonal plasticity noted at and distal to the injury epicenter in CX3CR1 ${ }^{-1-}$ mice was associated with changes in synaptogenesis. First, synapsin immunohistochemistry was used to quantify changes in presynaptic coverage on lumbar ventral horn motor neurons from 4 to $56 \mathrm{dpi}$. The number of synapsin-positive puncta were analyzed using two-way ANOVA with genotype and time postinjury as independent variables. There were significant main effects for both genotype $\left(F_{(1,30)}=5.81, p=0.0223\right)$ and time postinjury $\left(F_{(4,30)}=\right.$ $18.79, p<0.0001)$. At 4 dpi in both CX3CR $1^{+/+}$and CX3CR $1^{-/-}$ mice, synaptic density decreased $\sim 70 \%$ compared with uninjured levels (Fig. $5 A-K$ ). Over the next $10 \mathrm{~d}$, new synapses formed in both genotypes; however, only in $\mathrm{CX} 3 \mathrm{CR} 1^{-/-}$mice did new synapses form throughout the evaluation period. Indeed, by $56 \mathrm{dpi}$, synapsin labeling returned toward baseline (preinjury) levels only in CX3CR1 ${ }^{-/-}$mice (Fig. $5 \mathrm{~K}$ ). A significant increase in presynaptic coverage of motor neurons after SCI in CX3CR1 ${ }^{-1-}$ mice was confirmed via electron microscopy (Fig. $5 L-N$ ). The 


\section{$\mathrm{CX} 3 \mathrm{CR} 1^{+/+}$}
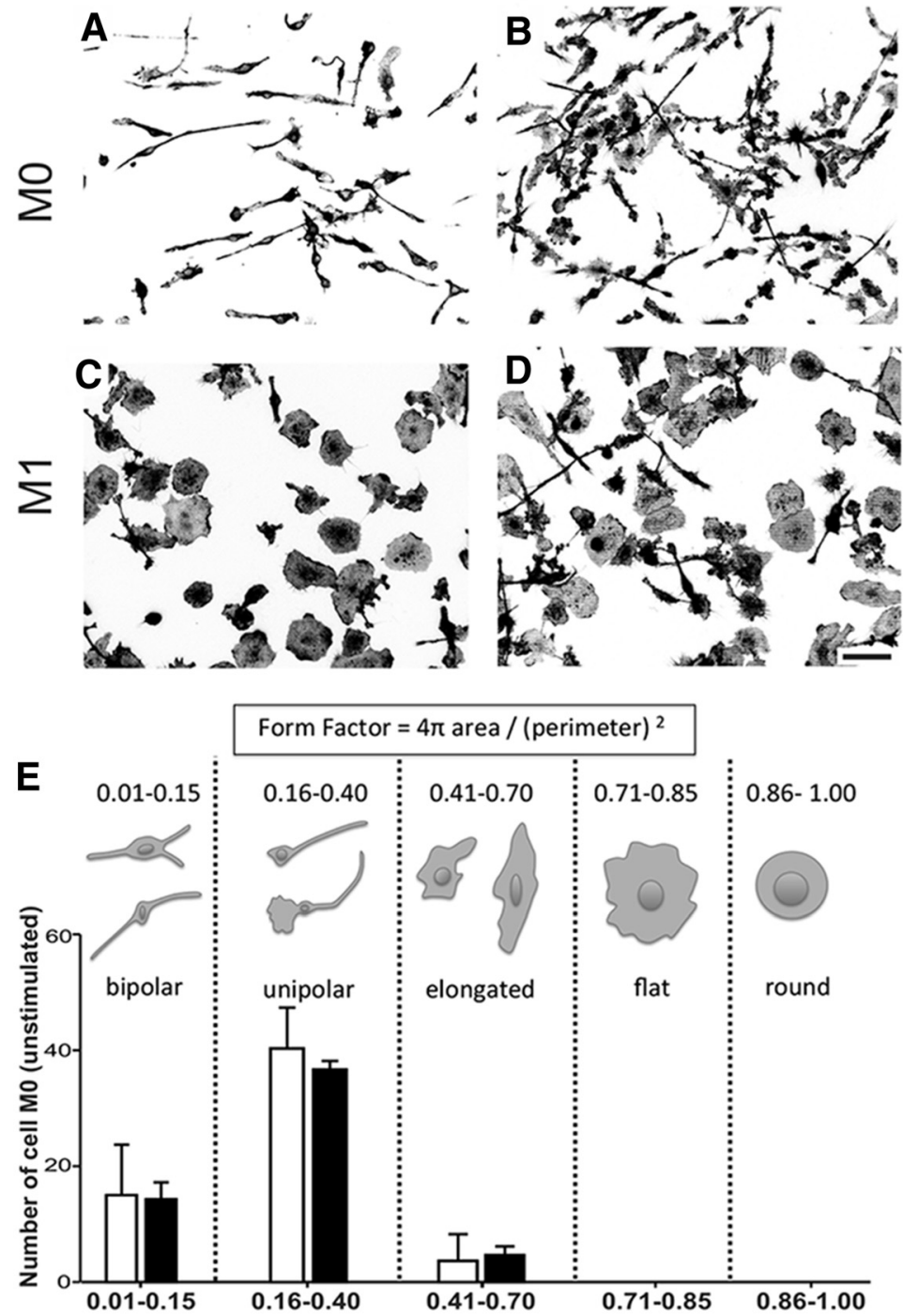

E

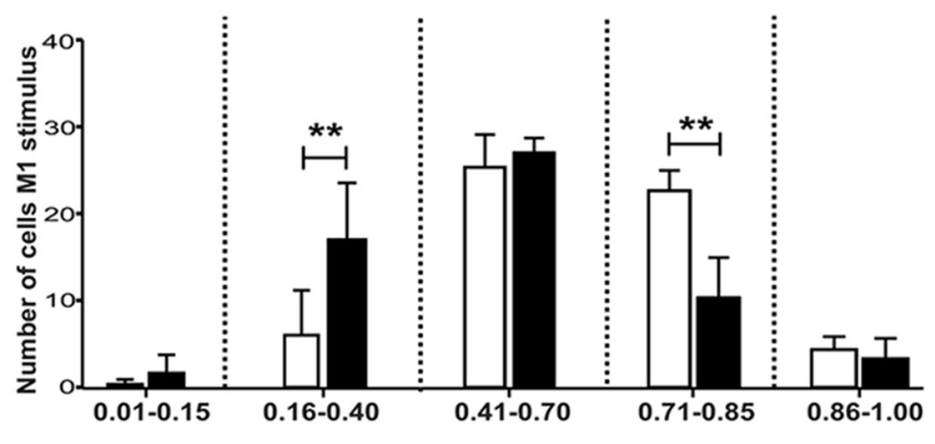

$\mathrm{CX} 3 \mathrm{CR}^{-1}$

B

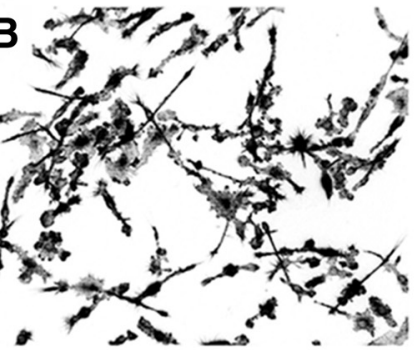

Form Factor

Form Factor
RT-PCR

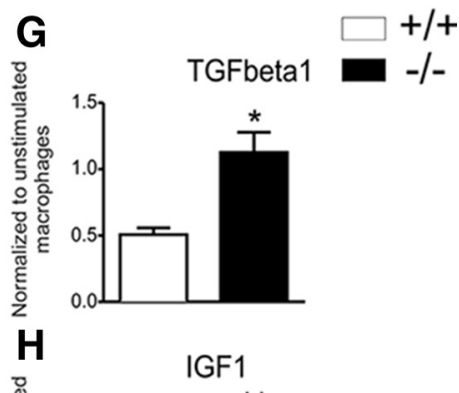

FGF2
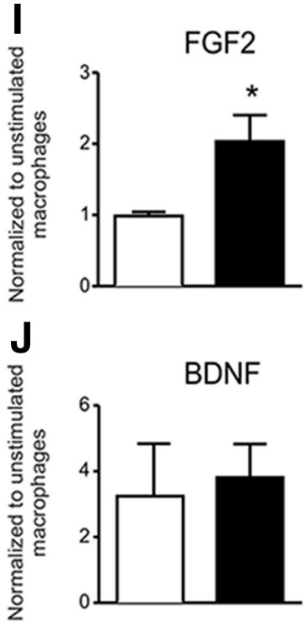

K

NT3
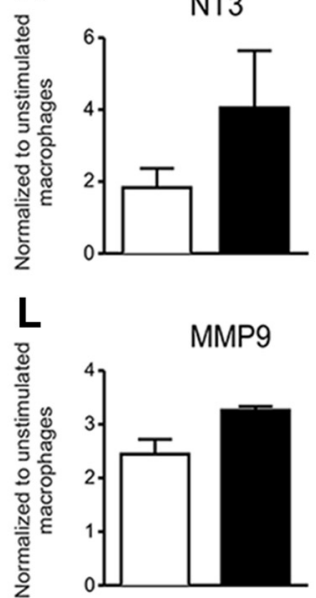

Figure 2. Inflammatory stimuli elicit a tissue-repair phenotype in $C X 3 C R 1^{-1-}$ macrophages. $A-D$, Morphology (phalloidin stain for actin) of control (unstimulated) $(A, B)$ macrophages or macrophages activated with inflammatory stimuli (IFN $\gamma+\mathrm{LPS})(\boldsymbol{C}, \boldsymbol{D})$. Inflammatory macrophages are easily distinguished by their large, flattened cell bodies with few filipodia. $\boldsymbol{E}, \boldsymbol{F}$, Genotypespecific changes in responsiveness of macrophages to inflammatory signals. Although CX3CR1 deletion has no effect on resting (unstimulated/M0) macrophage morphologies (E), only CX3CR1 WT $(+/+)$ macrophages consistently show dramatic FF changes (indicative of activation) in response to inflammatory signaling $(\boldsymbol{F}) . \mathbf{G}-\boldsymbol{L}, \mathrm{qRT}-\mathrm{PCR}$ analyses of inflammatory macrophages generated from $+/+$ or $-/-$ mice. Graphs are mean data from one of three independent replicate experiments. Data were calculated using the $\Delta \Delta C \mathrm{Ct}$ method (gene/18S ratio for control unstimulated macrophages). Inflammatory macrophages derived from $-1-$ mice show higher expression of genes encoding neurotrophic and gliogenic proteins. Data are mean \pm SEM obtained from $n=3$ replicate wells/group. ${ }^{*} p<0.05$ (Student's unpaired two-tailed $t$ test). ${ }^{* *} p<0.01$ (Student's unpaired two-tailed $t$ test). 
CX3CR1 $1^{+/+}$
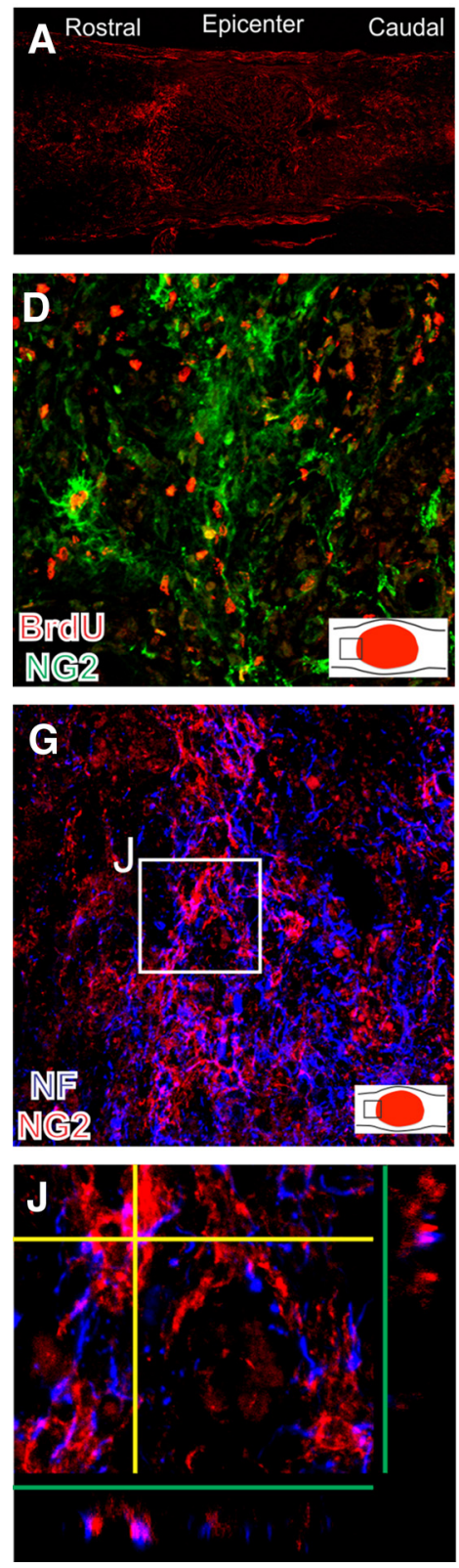

CX3CR1 ${ }^{-1}$
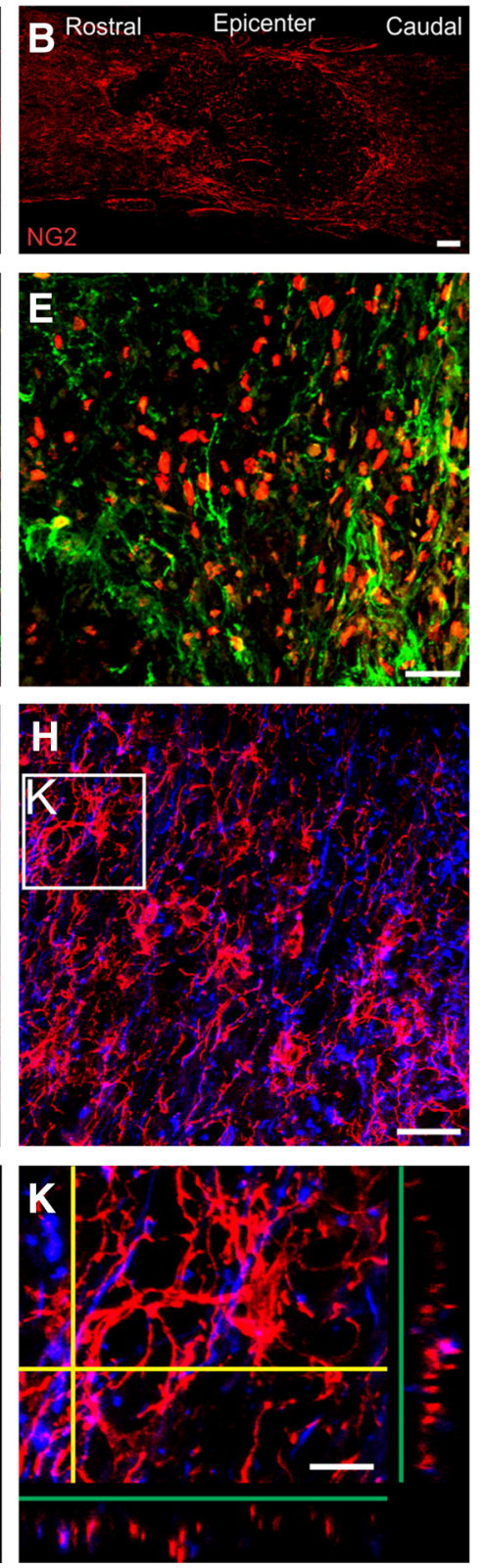

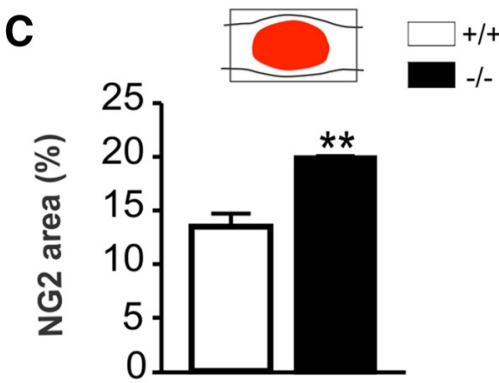

$\mathbf{F}$
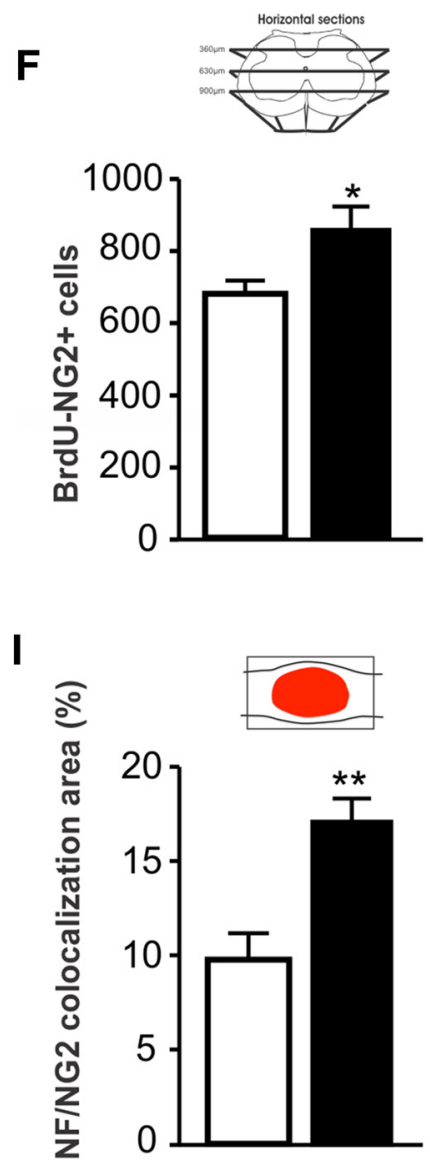

Figure 3. $C X 3 C R 1^{-/-}$macrophages create an environment that supports $N G 2$ glia and the growth or stability of axons. $A, B, N G 2$ staining of horizontal spinal cord sections from $(A) C X 3 C R 1^{+/+}$ or $(\boldsymbol{B}) \mathrm{CX} 3 \mathrm{CR} 1^{-l-}$ mice at $56 \mathrm{dpi}$. C, Graph represents area of NG2 labeling in a $302 \mu \mathrm{m}^{2}$ box centered on the epicenter. Schematic indicates measurement area. $\boldsymbol{D}, \boldsymbol{E}$, Double-labeling for BrdU (red) and NG2 ${ }^{+}$cells (green) near the lesion border. $\boldsymbol{F}$, Total number of NG2 ${ }^{+} /$BrdU ${ }^{+}$cells in a $1 \mathrm{~mm}$ section centered over the epicenter. Cells were quantified through the dorsoventral axis of the spinal cord in multiple planes of section as illustrated in the schematic. $\mathbf{G}-\boldsymbol{K}$, Double-labeling of neurofilament (blue) and NG2 (red) at the rostral interface of the lesion epicenter. $\boldsymbol{I}$, Percentage area of NG2 and NF colocalization. Schematic of spinal cord indicates measurement area. $\boldsymbol{J}, \boldsymbol{K}$, High-power magnifications of boxes in $\boldsymbol{G}, \boldsymbol{H}$. Note NG2 ${ }^{+}$cells wrapping axons $(\boldsymbol{K})$. Scale bars: $\boldsymbol{B}, 150 \mu \mathrm{m} ; \boldsymbol{D}, \boldsymbol{E}, 20$ $\mu \mathrm{m} ; \boldsymbol{G}, \boldsymbol{H}, 30 \mu \mathrm{m} ; \boldsymbol{J}, \boldsymbol{K}, 10 \mu \mathrm{m}$. Graphs are representative of a single experiment. Data are mean $\pm \mathrm{SEM} ; n=5+/+$ and $n=4-/-$ mice/group. ${ }^{*} p<0.05$ (Student's unpaired two-tailed $t$ test). ${ }^{* *} p<0.01$ (Student's unpaired two-tailed $t$ test).

overall (genotype $\times$ time postinjury) interaction was not significant.

Previously, we found that forelimb/hindlimb coordination was significantly improved after SCI in CX3CR $1^{-1-}$-deficient mice (Donnelly et al., 2011). Serotonergic axons play a critical role in modulating interlimb coordination, notably by strengthening inhibitory synaptic transmission to motor neurons (Ciranna, 2006; Bos et al., 2013; Gackière and Vinay, 2014). Given the increase in plasticity of $5-\mathrm{HT}^{+}$fibers around lumbar motor neurons in CX3CR1 ${ }^{-1-}$ mice (Fig. 4) and the dramatic increase in synaptic coverage of these neurons (Fig. 5), we next examined the relative density of inhibitory and excitatory presynaptic and postsynaptic densities on lumbar (laminae IX) spinal cord motor neurons.

First, immunolabeling for L-GAD, an enzyme involved in the synthesis of the inhibitory neurotransmitter GABA, was used to quantify $\mathrm{GAD} 67^{+}$puncta. Significantly more GAD $67^{+}$puncta were detected in $\mathrm{CX} 3 \mathrm{CR} 1^{-1-}$ mice, with overall numbers approaching levels found in naive, uninjured mice (Fig. 6A-D). We extended these analyses by double-labeling for VGAT (vesicular GABA transporter, presynaptic marker) and gephyrin, a protein responsible for organizing both glycine and GABA receptor subunits, both of which mediate postsynaptic inhibition in the spinal 

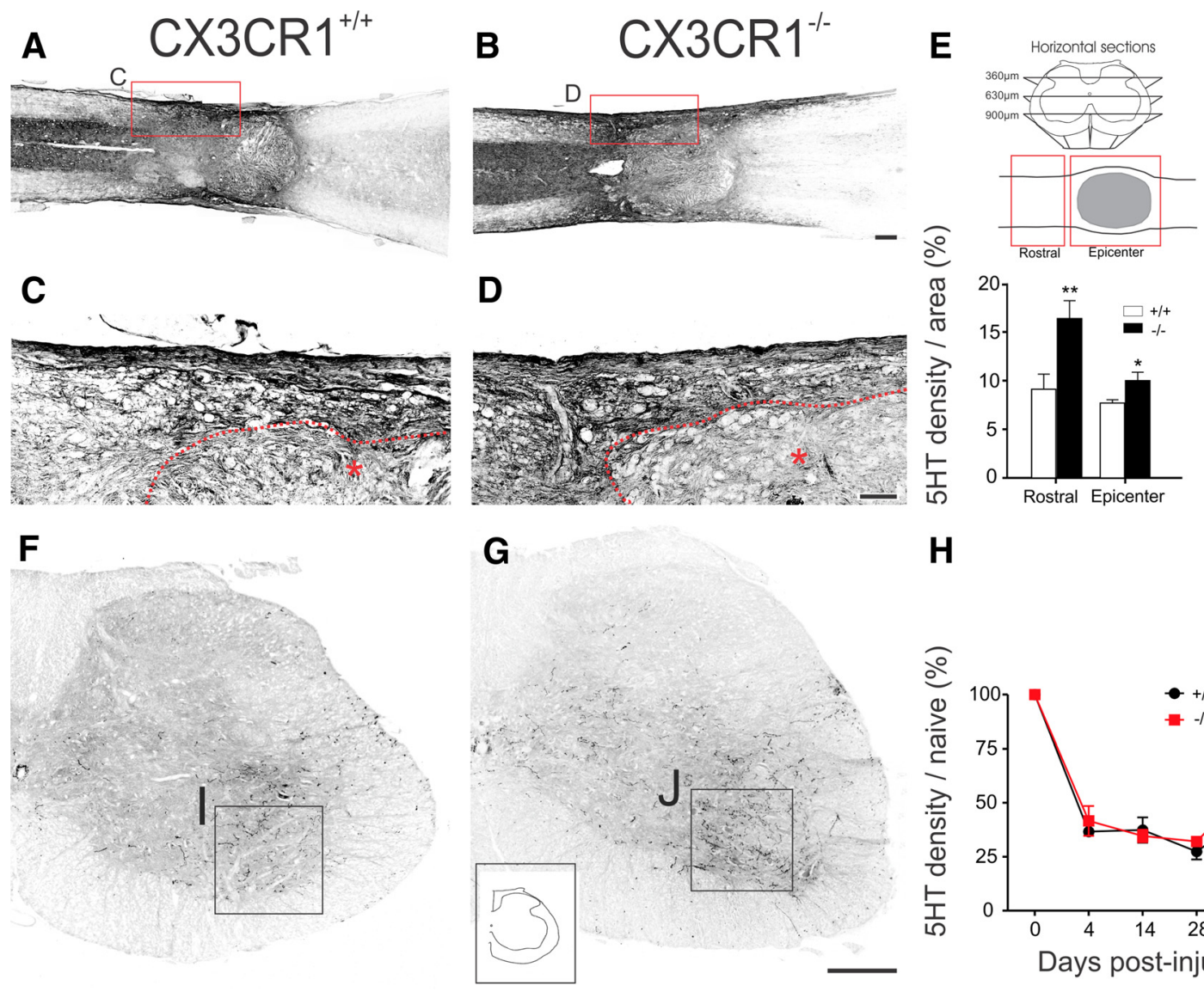

H
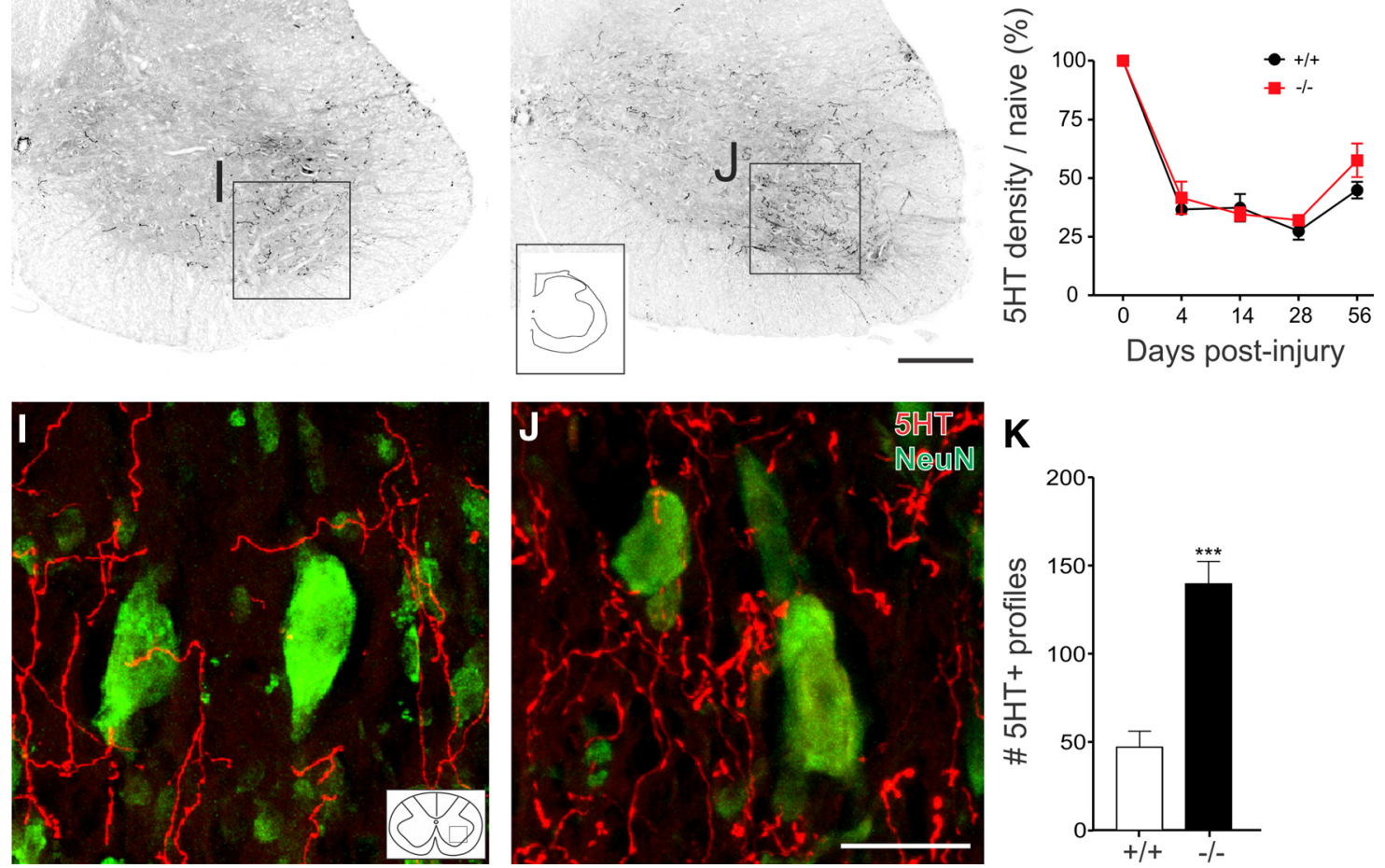

Figure 4. The density and distribution of serotonergic (5-HT) axons increase at and below the injury epicenter in $\mathrm{SCI} C X 3 \mathrm{CR}^{-1-}$ mice. $A, B$, Representative horizontal sections from $C X 3 C \mathrm{R} 1^{+/+}$ $(\boldsymbol{A}, \boldsymbol{C})$ and $\mathrm{CX} 3 \mathrm{CR}^{-1-}(\boldsymbol{B}, \boldsymbol{D})$ mice. Rostrocaudal orientation is left-to-right. $\boldsymbol{C}, \boldsymbol{D}$, High-magnification images of boxes in $\boldsymbol{A}, \boldsymbol{B}$. $\boldsymbol{C}, \boldsymbol{D}$, Red asterisks indicate lesion epicenter. Note the higher density of $5-\mathrm{HT}^{+}$axons at the rostral interface in $\mathrm{CX} 3 \mathrm{CR} 1^{-1-}$ mice. $E$, Schematic illustrates the horizontal planes through the dorsoventral axis of the spinal cord where 5 -HT immunoreactivity was quantified. Graph represents average $5-\mathrm{HT}$ density across three horizontal sections both rostral and at the lesion epicenter. $\boldsymbol{F}, \mathbf{G}$, Lumbar spinal hemi-cords showing 5-HT labeling in transverse

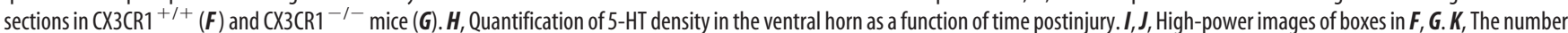
of $5-\mathrm{HT}^{+}$profiles in lumbar ventral horn. $\boldsymbol{E}, \boldsymbol{H}$, Graphs were generated from single experiments and were analyzed using two-way ANOVA with Bonferroni post tests. ${ }^{*} p<0.05 .{ }^{* *} p<0.01 . \mathbf{G}, n=$ $5+/+$ and $5-/-$ mice/group. $\boldsymbol{H}, n=3$ mice at day 0 and $n=4 /$ group at $4,14,28$, and 56 dpi. $\boldsymbol{K}$, Representative graph from two independent experiments using $n=5+/+$ and $-/-$ mice/group each time. ${ }^{* * *} p<0.001$ (Student's unpaired two-tailed $t$ test). Scale bars: $\boldsymbol{B}, 250 \mu \mathrm{m} ; \boldsymbol{D}, 200 \mu \mathrm{m} ; \mathbf{G}, 100 \mu \mathrm{m} ; \boldsymbol{J}, 40 \mu \mathrm{m}$. Data are mean \pm SEM.

cord (Tretter et al., 2012). Using this antibody combination, a significant increase of presynaptic/postsynaptic inhibitory puncta was detected on motoneurons in the lumbar spinal cord of CX3CR1 ${ }^{-1-}$ mice (Fig. $6 E-N$ ).

Motor synergies are also controlled by excitatory input to laminae IX neurons from motor cortex and segmental sensory pathways (Cowley and Schmidt, 1997; Alvarez et al., 2004; Landry et al., 2004; Persson et al., 2006; Rossignol et al., 2009; Levine et al., 2014). Therefore, combinations of the presynaptic markers VGlut1 and VGLut2 and postsynaptic marker Homer-1 were used to eval- uate postinjury changes in excitatory input to ventral horn motorneurons (Gutierrez-Mecinas et al., 2016). VGlut1 labels intraspinal synaptic contacts formed mostly by excitatory propriospinal fibers, whereas VGlut2 is expressed in synaptic terminals of both supraspinal and intraspinal neurons. Consistent with labeling patterns described previously in rats (Oliveira et al., 2003; Landry et al., 2004; Persson et al., 2006), VGlut1 labeling was enriched in the deeper laminae of the gray matter dorsal horn and lamina VII of both WT and CX3CR1 ${ }^{-1-}$ mice, although significantly more excitatory presynaptic/postsynaptic puncta 


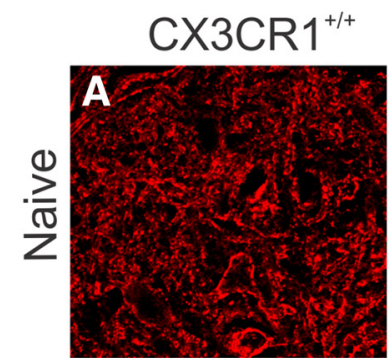

\section{CX3CR $1^{-1-}$}
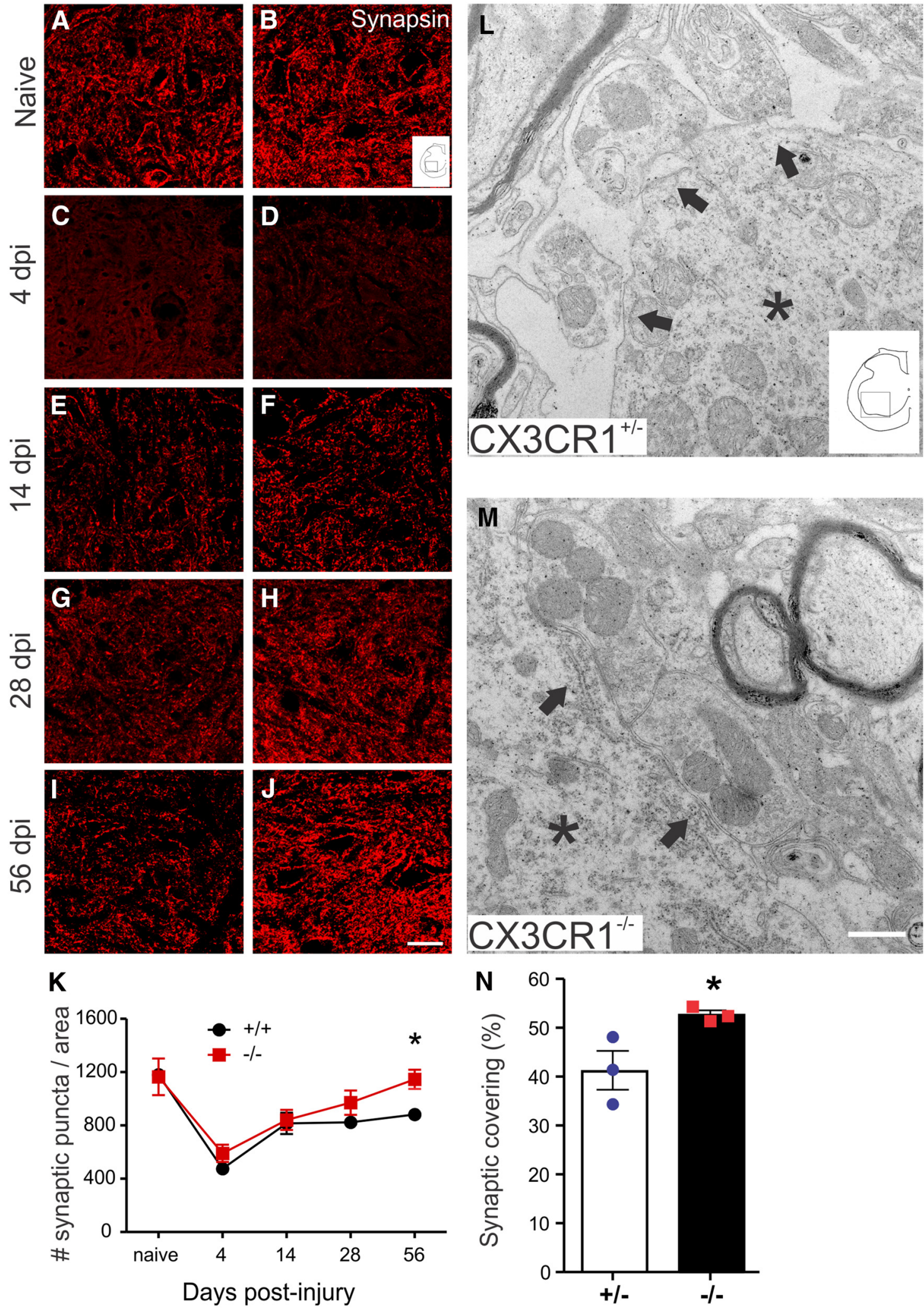

Figure 5. Synaptic plasticity is enhanced in spinal cord lumbar ventral horn after SCl in CX3CR1 ${ }^{-1-}$ mice. Representative images illustrate time-dependent changes in synapsin labeling in lumbar spinal cord of CX3CR1 ${ }^{+/+}(\boldsymbol{A}, \boldsymbol{C}, \boldsymbol{E}, \boldsymbol{G}, \boldsymbol{I})$ and $\mathrm{CX} 3 \mathrm{CR} 1^{-/-}(\boldsymbol{B}, \boldsymbol{D}, \boldsymbol{F}, \boldsymbol{H}, \boldsymbol{J})$ mice. $\boldsymbol{K}$, Quantification of synapsin-positive puncta as a function of time after $S C l$ within ventral horn. $\boldsymbol{L}, \boldsymbol{M}, \mathrm{Ult}$ trastructural images of synapses apposed to lumbar motor neurons in CX3CR1 ${ }^{+/-}(\boldsymbol{L})$ and $C X 3 C R 1^{-/-}(\boldsymbol{M})$ mice. Asterisks indicate motor neuron cytoplasm. Arrows indicate presynaptic receptors contacting motor neuron surfaces. $\boldsymbol{N}$, Percentage of motor neuron circumference covered by synapses. $\boldsymbol{K}, \boldsymbol{N}$, Graphs generated from independent experiments, in $(\boldsymbol{K})$ naive and $4 \mathrm{dpi}, n=3+/+$ and $-/-$ mice/group; $14 \mathrm{dpi}, n=5 /$ group; 28 and $56 \mathrm{dpi}, n=5$ /group and $n=4 /$ group. $\boldsymbol{N}, n=3$ mice/group. $\boldsymbol{K}$, Data analyzed using two-way AN0VA with Bonferroni post tests. $\boldsymbol{N}$, Data were analyzed using Student's unpaired two-tailed $t$ test. ${ }^{*} p<0.05$. Scale bars: $J, 20 \mu \mathrm{m} ; \boldsymbol{M}, 0.5 \mu \mathrm{m}$. Data are mean \pm SEM. 


\section{GAD67}
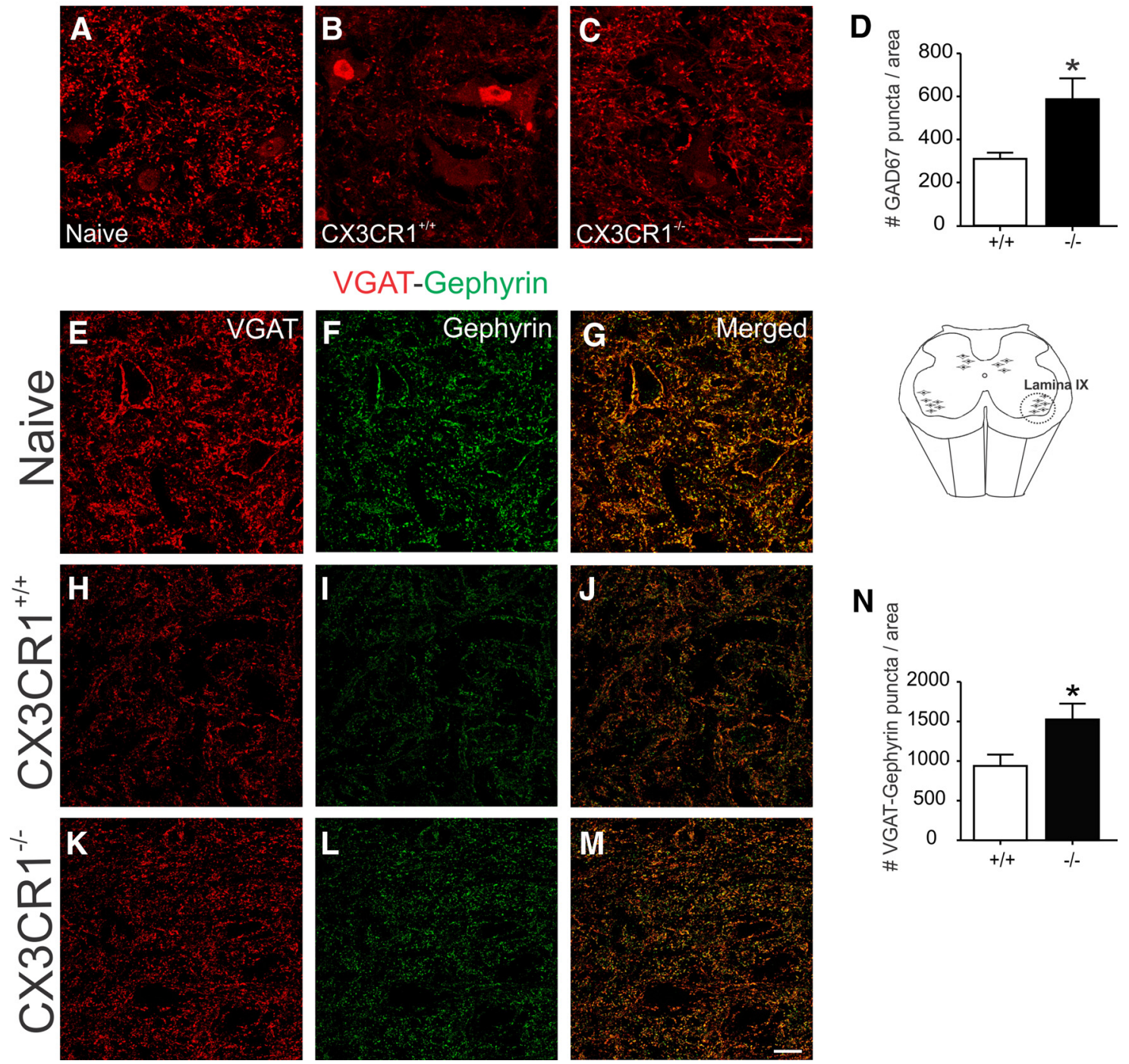

Figure 6. Plasticity of inhibitory synapses is enhanced in spinal cord lumbar ventral horn after SCl in CX3CR1 ${ }^{-1-}$ mice. GAD67 labeling in transverse sections in the lumbar (L3/L4) spinal cord of (A) naive, $(\boldsymbol{B}) \mathrm{CX} 3 \mathrm{CR} 1^{+/+}$, and $(\boldsymbol{C}) \mathrm{CX} 3 \mathrm{CR} 1^{-/-}$mice at $56 \mathrm{dpi}$. $\boldsymbol{D}$, Quantification of $\mathrm{GAD} 67^{+}$synaptic puncta in the ventral horn of $\mathrm{CX3CR1^{+/+ }}$ and $\mathrm{CX} 3 \mathrm{CR} 1^{-/-}$mice. $\boldsymbol{E}, \boldsymbol{H}, \boldsymbol{K}, \mathrm{VGAT}$ (presynaptic receptor, red) and $(\boldsymbol{F}, \boldsymbol{I}, \boldsymbol{L})$ gephyrin (postsynaptic receptor, green) double-labeling in naive $(\boldsymbol{E}-\boldsymbol{G}), \mathbf{S C I C X} 3 \mathrm{CR} 1^{+/+}(\boldsymbol{H}-\boldsymbol{J})$, and $\mathrm{CX} 3 \mathrm{CR} 1^{-/-}(\boldsymbol{K}-\boldsymbol{M})$ mice. $\boldsymbol{G}, \boldsymbol{J}, \boldsymbol{M}$, Merged images represent VGAT and gephyrin colocalization. $N$, Quantification of VGAT-gephyrin colocalized synaptic puncta in the ventral horn of WT $(+/+)$ and CX3CR1-deficient ( $-/-$ ) mice. Schematic of spinal cord illustrating lamina IX of lumbar spinal cord where synaptic puncta were quantified. Graphs generated from a single experiment; $n=5+/+$ and $n=4-/-$ mice/group. * $p<0.05$ (Student's unpaired two-tailed $t$ test). Scale bars: $C, M, 20 \mu \mathrm{m}$. Data are mean \pm SEM.

colocalized with laminae VII neurons in CX3CR1 ${ }^{-1-}$ mice (Fig. $7 A-I)$. VGlut2 is more widely distributed throughout the spinal gray matter (Oliveira et al., 2003; Persson et al., 2006). Quantification of VGlut2/Homer-1 colocalization also revealed significantly more excitatory synapses in laminae IX neurons in CX3CR1 ${ }^{-1-}$ mice (Fig. $7 J-R$ ). Together, these data indicate that the relative magnitude of excitatory and inhibitory inputs on lumbar motor neurons is increased after SCI in CX3CR $1^{-1-}$ mice, presumably providing a more "normal" substrate for modulating motor neuron activities.

\section{CX3CR1 deletion impairs inflammatory signaling in spinal} cord microglia remote from the injury epicenter

The remarkable changes in axonal and synaptic plasticity in remote (lumbar) regions of the injured spinal cord of CX3CR $1^{-1-}$ mice could result from the reduced inflammatory burden with neuroprotection at the injury epicenter (see above). However, thoracic SCI can elicit inflammatory signaling in microglia remote from the lesion site, and such changes have been shown to impair sensory and locomotor function and spinal learning (Detloff et al., 2008; Hansen et al., 2013; Grau et al., 2014; Shin et al., 2014). To determine whether lumbar spinal microglia respond differently after SCI in CX3CR1 $1^{-1-}$ compared with WT mice, we quantified the proportional area (PA) of $\mathrm{Ibal}^{+}$microglia, a morphological index of activation (Blackbeard et al., 2007; Donnelly et al., 2009) and relative proportions of p38MAPK ${ }^{+}$ microglia.

After thoracic SCI in both WT and CX3CR1 ${ }^{-1-}$ mice, microglia adopt an "activated" phenotype at and well beyond the lesion epicenter, including lumbar spinal levels where activated microglia are distributed throughout white matter and also surrounding motor neuron soma (illustrated using tissue from a CX3CR $1^{+/+}$mouse in Fig. $8 A, B$ ). However, a comparison of microglia activation (Iba1 PA) between genotypes and as a function of distance from 

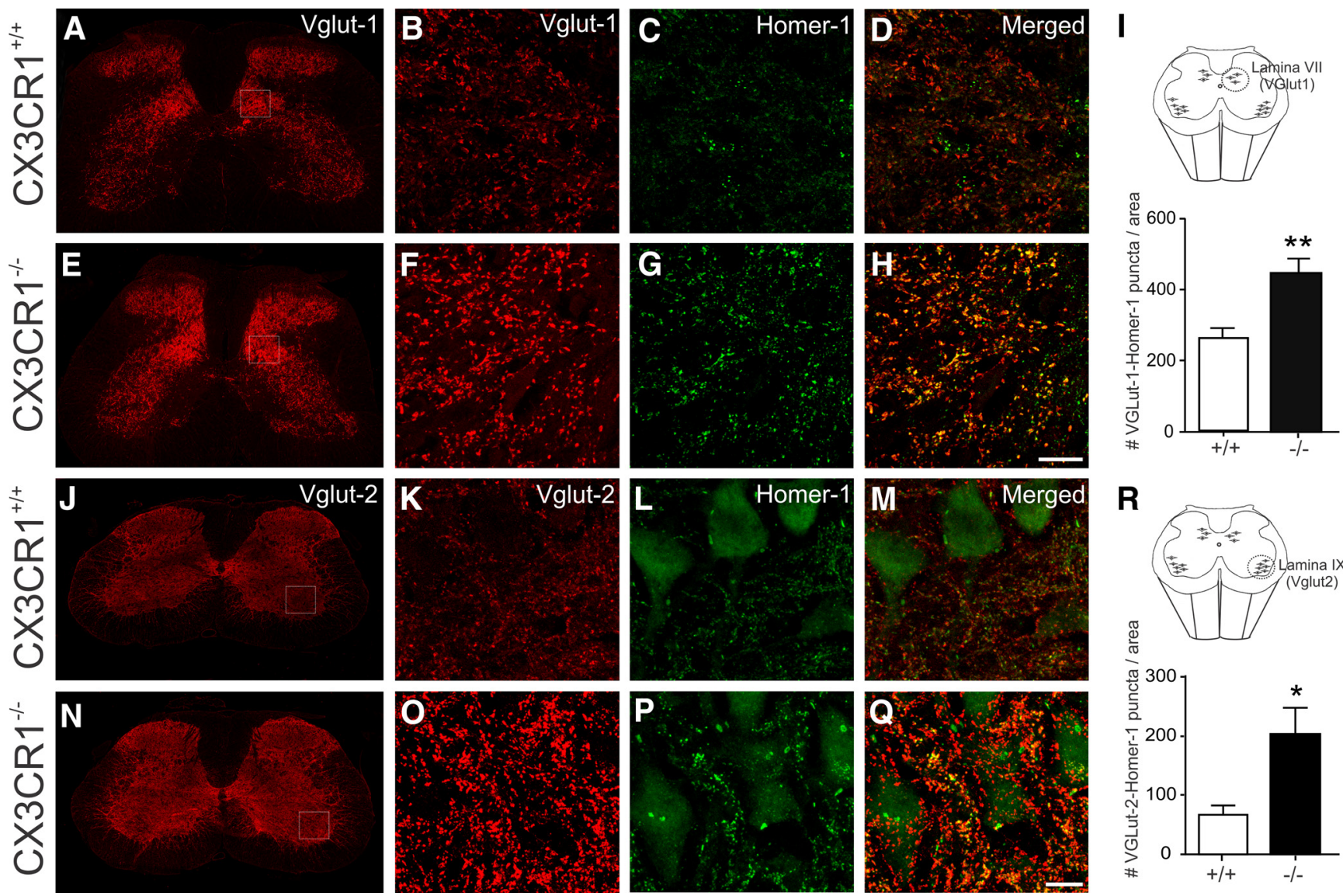

Figure 7. Plasticity of excitatory synapses is enhanced in spinal cord lumbar ventral horn after SCl in $C X 3 C_{C} 1^{-1-}$ mice. Immunolabeling for presynaptic VGlut1 $(\boldsymbol{A}, \boldsymbol{B}, \boldsymbol{E}, \boldsymbol{F})$ and VGlut2 $(\boldsymbol{J}, \boldsymbol{K}, \boldsymbol{N}$, $\mathbf{0})$ and $(\boldsymbol{C}, \boldsymbol{G}, \boldsymbol{L}, \boldsymbol{P})$ postsynaptic Homer-1 receptors at $56 \mathrm{dpi}$ in $\mathrm{CX}_{3} \mathrm{CR} 1^{+/+}$and $\mathrm{CX} 3 \mathrm{CR} 1^{-/-}$mice. Merged image of double-labeling for VGlut1 or VGlut 2 and Homer-1 in lamina VII (D, $\left.\boldsymbol{H}\right)$ and IX $(\boldsymbol{M}, \mathbf{Q})$, respectively. $\boldsymbol{I}, \boldsymbol{R}$, Schema indicate gray matter laminae where puncta were quantified. The number of excitatory synaptic puncta in $C X 3 C \mathrm{CR} 1^{-\prime-}$ mice is increased in ventral horn lamina VII $(\boldsymbol{I})$ and $I X(R)$, respectively, relative to $+/+$ mice. Graphs are representative of a single experiment; $n=5+/+$ and $n=4-/-$ mice/group. ${ }^{*} p<0.05$ (Student's unpaired two-tailed $t$ test). ${ }^{* *} p<0.01$ (Student's unpaired two-tailed $t$ test). Scale bars: $\boldsymbol{H}, \mathbf{Q}, 20 \mu \mathrm{m}$. Data are mean \pm SEM.

the lesion epicenter revealed a significant main effect of both genotype $\left(F_{(1,13)}=12.04, p=0.0042\right)$ and spinal level $\left(F_{(1,13)}=\right.$ $4.87, p=0.0459)$. Microglia activation was significantly reduced in $\mathrm{CX} 3 \mathrm{CR} 1^{-1-}$ mice. These effects were most prominent in the lower lumbar (L4-L5) spinal cord (Fig. 8C-E). The (genotype $\times$ spinal level) interaction was not significant.

p38MAPK phosphorylation, an indicator of neurotoxic inflammatory signaling (Herlaar and Brown, 1999; Saklatvala, 2004), also was reduced in CX3CR $1^{-/-}$microglia relative to WT microglia (Fig. 8I-K). Immunofluorescent double-labeling confirmed that p38MAPK is expressed mainly by microglia (and not astrocytes) (Fig. $8 L-N$ ). These data indicate that CX3CR1 regulates inflammatory signaling and cytoskeletal dynamics in remotely activated microglia.

Dendritic spine plasticity is enhanced in lumbar motor neurons of CX3CR1-deficient mice

In WT mice, postinjury activation of microglia with increased inflammatory signaling at remote spinal levels could indicate that these glia are responding to chronic axonal degeneration, motor neuron denervation, and synapse loss. To assess this, we quantified fine details of neuron morphology, including soma size, number of dendrites, and the number and length of dendritic spines on Golgi-stained motor neurons located throughout the ventral horn (lamina IX) of the L2-L5 spinal cord at $56 \mathrm{dpi}$.
Surprisingly, no genotype-specific differences were found for any of these parameters (Fig. $9 A-I$ ).

Because microglia affect synaptic plasticity and because indices of microglia activation differ between genotypes with respect to lumbar spinal level (Fig. 8), we next analyzed dendritic spine morphology taking care to bin data by lumbar segment (L2-L3 vs L4-L5). The maturation status of newly formed dendritic spines and the functional state of ongoing synaptic transmission correlate with dendritic spine morphology (Risher et al., 2014). Fully mature synapses are associated with bulbous or mushroom-shaped spines containing many neurotransmitter receptors. Conversely, longer filopodial-like spines that help initiate synaptic contact are predictive of immature synapses (Yuste and Bonhoeffer, 2001; Hayashi and Majewska, 2005). A rapid and unbiased Golgi analysis technique was used to measure the length and diameter of dendritic spines, which were then classified as filopodial or thin (immature) or mushroom (mature) (Risher et al., 2014). Immature synapses were more frequent at caudal lumbar levels (L3L4), whereas mature synapses were more frequent at the L2-L3 level. Importantly, in CX3CR1 ${ }^{-1-}$ mice, in which microglia activation and inflammatory signaling are reduced relative to WT microglia, these spinal level-dependent differences were magnified (Fig. 9L-N). The percentage of each spine classification was analyzed using two-way ANOVA with genotype and spinal level as independent variables. There was a significant main effect of 

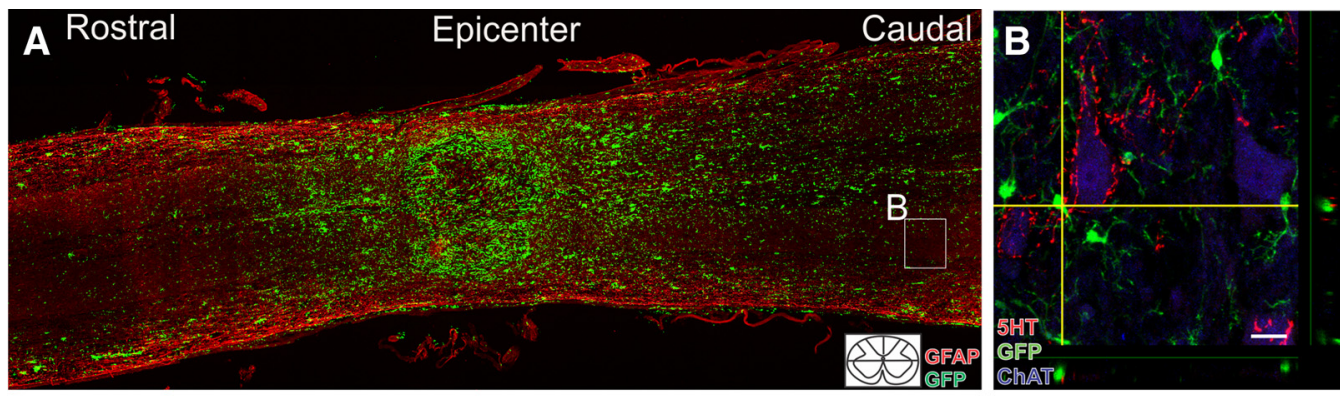

Iba-1
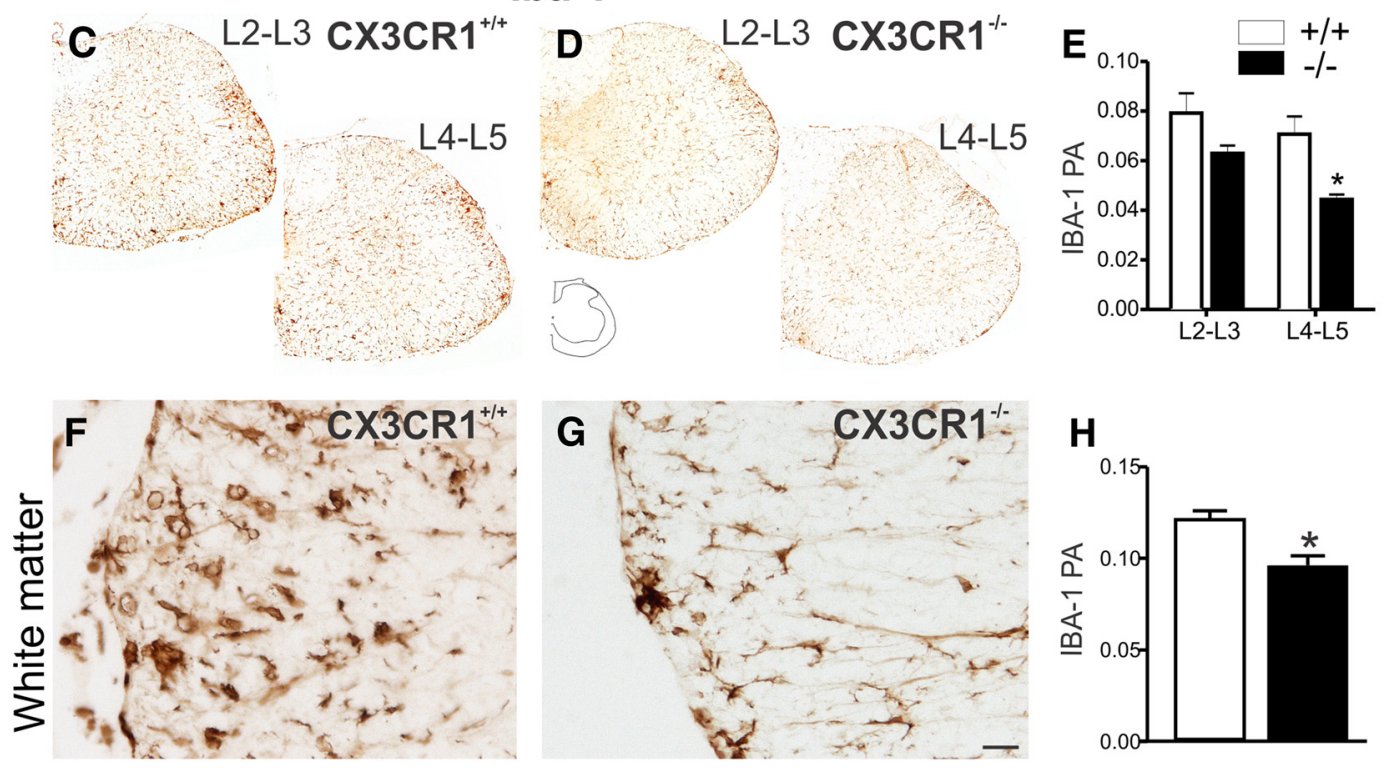

P38MAPK
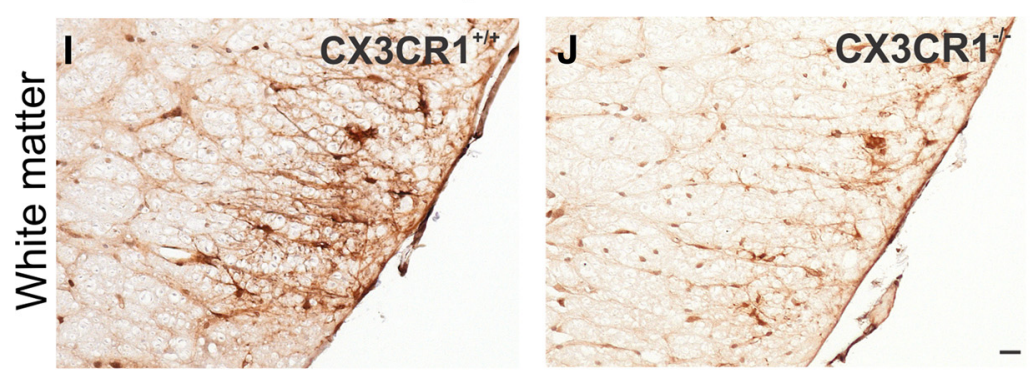

$\mathbf{K}$
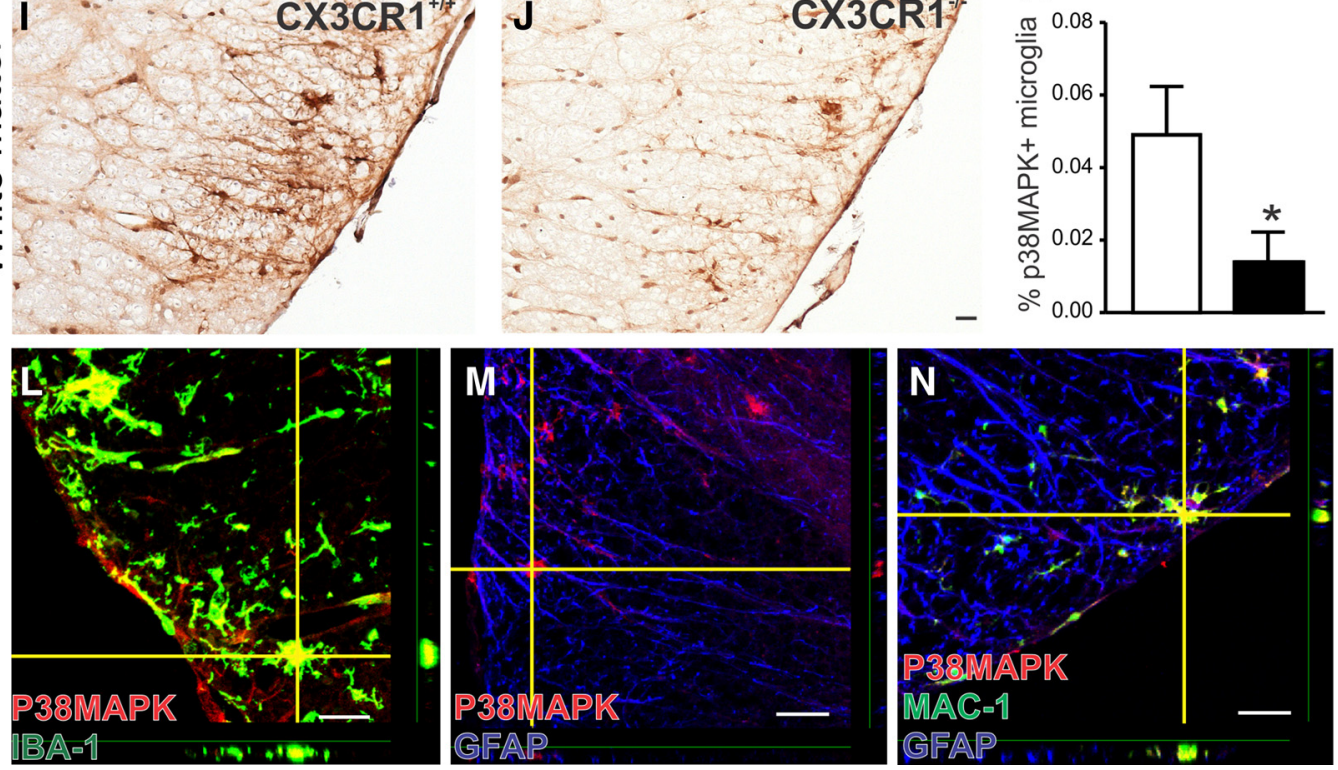

Figure 8. Microglia activation is reduced in lumbar spinal cord of $\mathrm{CX} 3 \mathrm{CR} 1^{-1-}$ mice after thoracic SCl. A, GFAP labeling (red) defines lesion margins, and activated microglia (GFP; green) are found within and several segments above and below the injury epicenter at $56 \mathrm{dpi}$ (horizontal section centered on the injury site). $\boldsymbol{B}$, Triple labeling for 5 -HT (red), GFP (green), and ChAT (blue) shows microglia $\left(\right.$ GFP $\left.{ }^{+}\right)$contacting motor neurons and 5 -HT terminals in lumbar spinal cord. C, D, F, G, Activated microglia in lumbar spinal cord labeled with Iba-1 in $C X 3 C R 1^{+/+}(C, F)$ and $C X 3 C R 1^{-/-}$ $(\boldsymbol{D}, \mathbf{G})$ mice. $\boldsymbol{E}$, IBA-1 proportional area measurement at (L2-L3) and (L4-L5) spinal levels. $\boldsymbol{F}-\boldsymbol{H}$, High-power images of Iba-1 ${ }^{+}$microglia in white matter show genotype specific differences in morphology in lumbar ventral horn (shown in L2-L4). $I-\boldsymbol{K}$, Genotype-specific differences exist for p38MAPK immunolabeling in lumbar spinal cords of CX3CR1 ${ }^{+/+}(\boldsymbol{I})$ and CX3CR1 ${ }^{-/-}(\boldsymbol{J})$ mice. $\boldsymbol{L}-\mathbf{N}$, Double-labeling for p38MAPK (red, $\boldsymbol{L}-\boldsymbol{N}$ ), Iba- 1 (green, $\boldsymbol{L})$, MAC-1 (green, $\boldsymbol{N}$ ), and GFAP (blue, $\boldsymbol{M}, \boldsymbol{N}$ ) reveals that p38MAPK is predominantly expressed by microglia (Iba1 and Mac1 ${ }^{+}$cells). $\boldsymbol{E}-\boldsymbol{K}$, Data were generated from a single experiment using $n=5+/+$ and $n=4-/-$ mice/group. $\boldsymbol{E}$, Data were analyzed using two-way ANOVA with Bonferroni post tests. $\boldsymbol{H}, \boldsymbol{K}$, Data were analyzed using Student's unpaired two-tailed $t$ test. ${ }^{*} p<0.05$. Scale bars: $\boldsymbol{B}, \mathbf{G}, \mathbf{J}, \mathbf{L}-\mathbf{N}, 20 \mu \mathrm{m}$. Data are mean \pm SEM. 

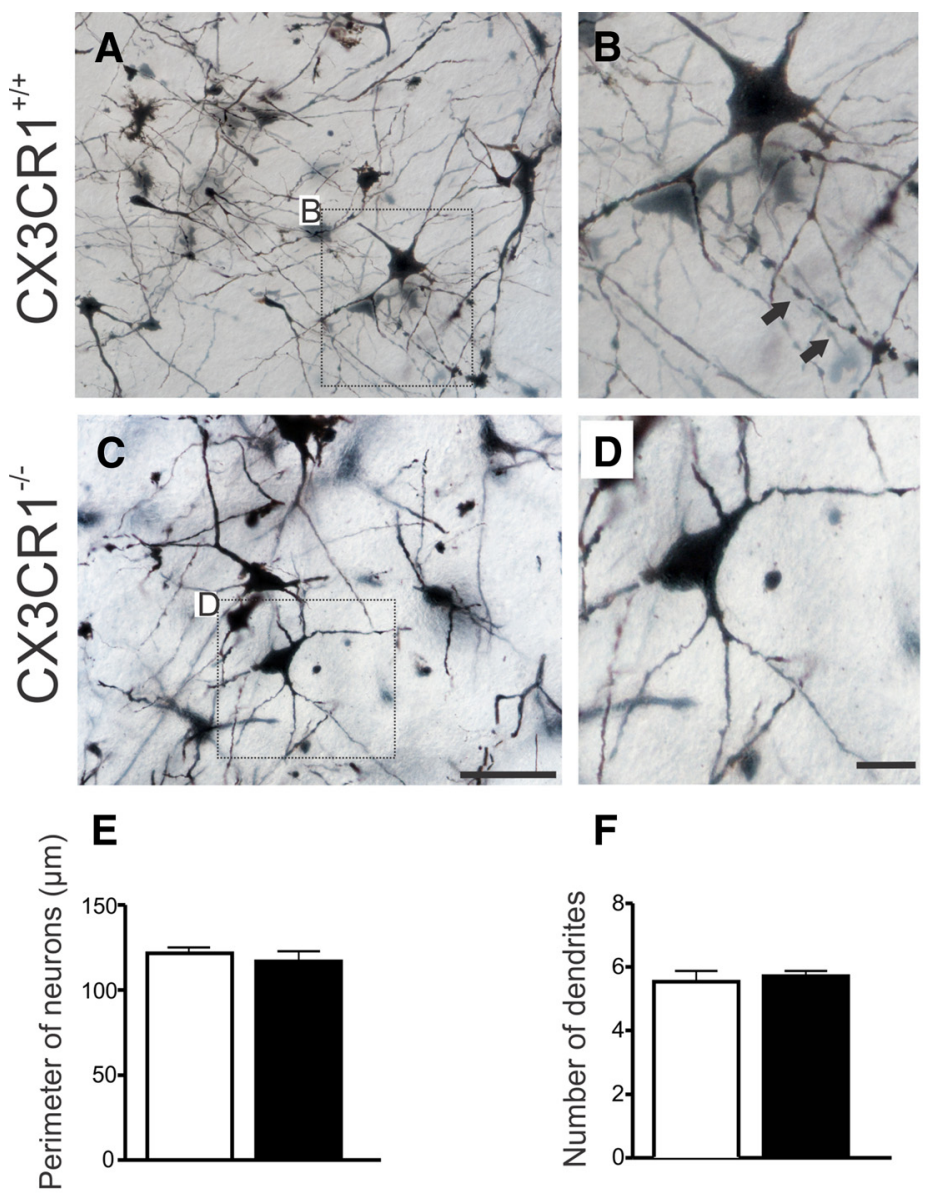

$\mathbf{F}$
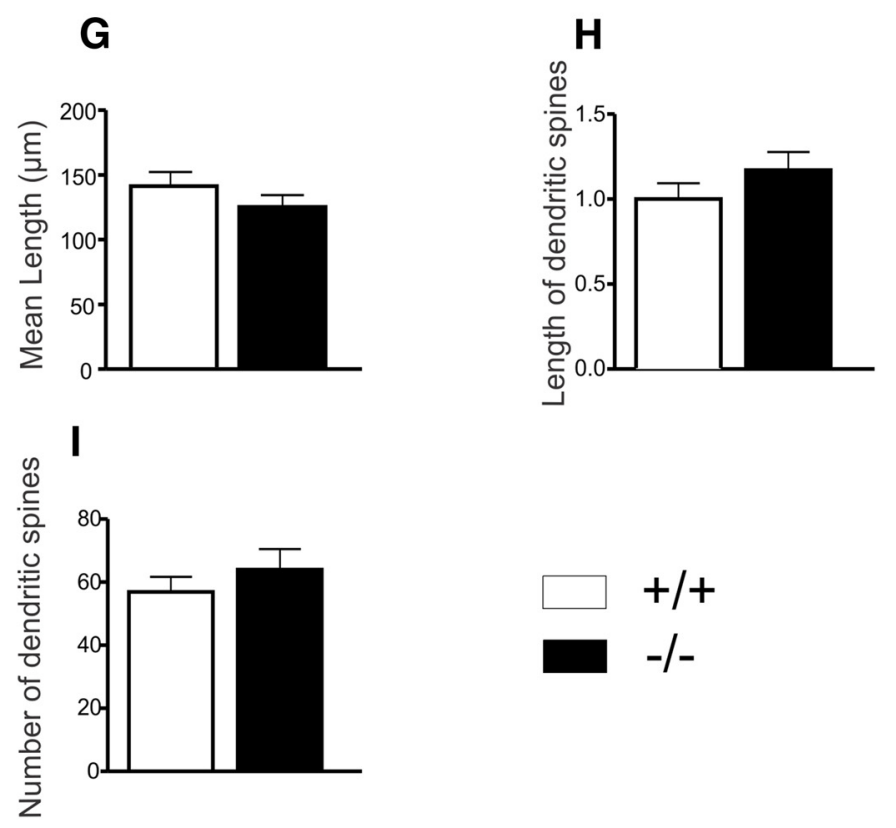

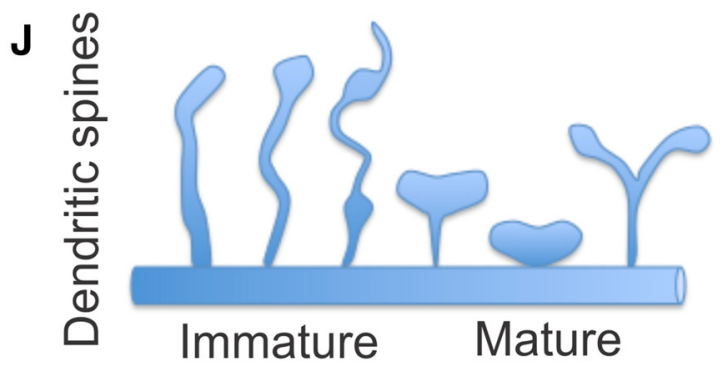

K

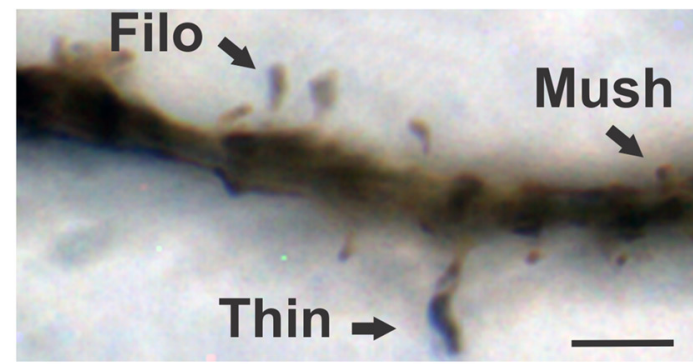

$\mathbf{L}$

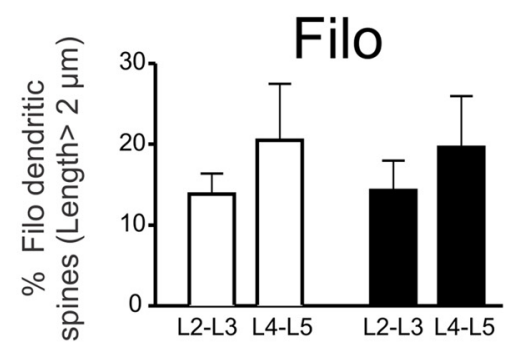

M

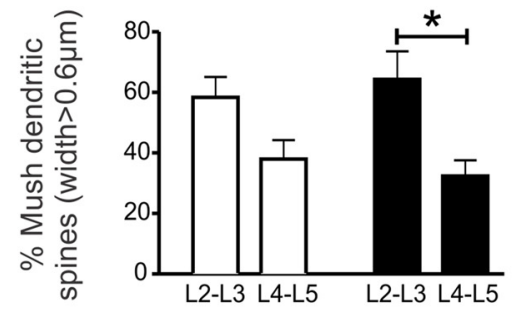

N

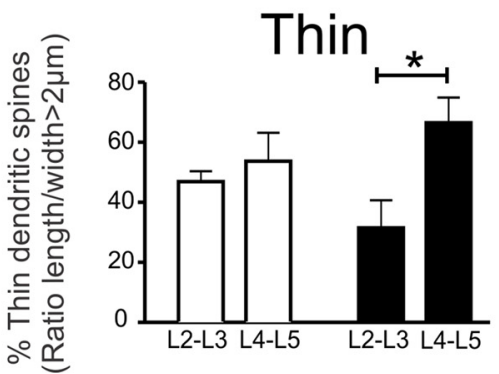

Figure 9. Dendritic spine plasticity is enhanced in motor neurons of $C X 3 C R 1^{-1-}$ mice. Golgi-Cox stain in lumbar spinal cord of CX3CR1 ${ }^{+/+}(A, B)$ and $C X 3 C R 1^{-1-}(C, D)$ mice at 56 dpi. $B$, Arrows indicate the presence of beaded dendrites (see also Fig. 10). $\boldsymbol{E}-\boldsymbol{I}$, Motor neuron perimeter, dendrite number, mean dendrite length, length of dendritic spines, and number of dendritic spines. $\boldsymbol{J}$, Schematic showing morphology of mature and immature dendritic spines. $\boldsymbol{K}$, High-power image showing filopodial (filo), mushroom (mush), and thin of dendritic spine morphologies. $\boldsymbol{L}-\boldsymbol{N}$, Quantification of the geometric characteristics of dendritic spines at L2-L3 and L4-L5 spinal levels. L, Immature (Filo) spines. M, Mature (Mush) spines width $>0.6 \mu \mathrm{m}$. N, Thin spines with a ratio of length/width $>2 \mu \mathrm{m}$ (immature). A significant switch of mature synapses to immature synapses occurs only in CX3CR1 ${ }^{-1-}$ mice. $E-N$, Data were generated from a single experiment using $n=5+/+$ and $n=4-/-$ mice/group. $L-N$, Data were analyzed using two-way ANOVA with Bonferroni post tests. $E-I$, Data were analyzed using Student's unpaired two-tailed $t$ test. ${ }^{*} p<$ 0.05. Scale bars: $\boldsymbol{A}, \boldsymbol{C}, 100 \mu \mathrm{m} ; \boldsymbol{B}, \boldsymbol{D}, 50 \mu \mathrm{m} ; \boldsymbol{K}, 1 \mu \mathrm{m}$. Data are mean \pm SEM. 
spinal level for both mushroom $\left(F_{(1,14)}=13.76, p=0.0023\right)$ and thin spines $\left(F_{(1,14)}=6.03, p=0.0278\right)$. There also was a main effect of genotype for thin spines $\left(F_{(1,14)}=6.03, p=0.0278\right)$. The (genotype $\times$ spinal level) interaction was not significant. The presence of more immature dendritic spines in caudal spinal cord of CX3CR1 $1^{-1-}$ mice, together with the data in Figures 56-7 showing enhanced synaptic plasticity at similar levels in these mice, indicates that CX3CR1 signaling may normally inhibit microglia-dependent synapse formation.

\section{CX3CR1 deficiency enhances synapse formation in part by preserving dendritic arbors}

When evaluating Golgi-stained neurons, varicosities were detected in a subset of dendritic arbors (Figs. 9B, 10A,B). These may represent early stages of cytoskeletal dysfunction and neuron degeneration. Microglia can release glutamate, and excessive release of glutamate into the extracellular space can cause structural collapse in neurons, including the formation of dendritic varicosities (Ikegaya et al., 2001; Greenwood and Connolly, 2007; Greenwood et al., 2007). An unbiased quantitative comparison of the size and numbers of varicosities in neurons from Figure 9 revealed smaller and fewer dendritic varicosites in CX3CR $1^{-1-}$ mice relative to WT mice (Fig. 10C,D).

To determine whether microglia cause these varicosities to form, microglia from WT or CX3CR $1^{-1-}$ mice were cocultured with primary cortical neurons (Fig. 10E-G). Although we found varicosities on dendrites cocultured either with $\mathrm{WT}$ and $\mathrm{CX} 3 \mathrm{CR} 1^{-1-}$ microglia, more varicosities were found formed on dendrites when cocultured with WT microglia (Fig. 10F,K). To determine whether these effects were caused by cell contact or soluble factors released by microglia, a separate culture of cortical neurons was exposed to medium conditioned by microglia isolated from WT or CX3CR $1^{-1-}$ mice (Fig. 10H-J). Again, more dendritic varicosities formed when neurons were exposed to WT microglia-conditioned media (Fig. 10I,L). These data are consistent with the in vivo data (Fig. $10 A, B$ ) and indicate that microglia adversely affect dendrite structure via release of toxic soluble factors produced downstream from CX3CR1 signaling. Whether these varicosities indicate imminent degeneration or loss of function is not known. Moreover, the precise nature of the soluble factor(s) has not been determined.

\section{Discussion}

Data in this report indicate that deletion of CX3CR1 in microglia and macrophages is neuroprotective (spares myelinated axons) and improves indices of endogenous repair, both at the lesion epicenter and in spared white and gray matter (e.g., serotonergic axon growth/sprouting, NG2 cell proliferation), both proximal and distal to the epicenter.

The benefits of CX3CR1 deletion may be explained by functional changes in microglia and macrophages. WT microglia and macrophages activated with inflammatory stimuli become neurotoxic and less supportive of endogenous repair (Kigerl et al., 2009; Miron et al., 2013; Kroner et al., 2014; Gensel et al., 2015). However, the same inflammatory stimuli cause CX3CR1 $1^{-1-}$ macrophages to increase expression of FGF-2, TGF- $\beta 1$, and IGF1 mRNA. Proteins encoded by these genes are known to be secreted by macrophages and can promote neuroprotection (Diemel et al., 2003; Frost et al., 2003; Suh et al., 2013; Cohen et al., 2014). Some of these proteins also are likely responsible for increasing survival, differentiation, and proliferation of NG2 cells (McTigue et al., 2000, 2001; Levine, 2016).
After SCI, NG2 ${ }^{+}$cell numbers increase inside the lesion and at the interface between injured and spared tissue (Lytle et al., 2006, 2009; Tripathi and McTigue, 2007; Wu et al., 2010). This stereotypical response is augmented in CX3CR1 ${ }^{-1-}$ mice. Even though NG2 is designated as an axon-growth inhibitory proteoglycan, it also can act as a substrate for growing axons (Tan et al., 2005, 2006; Petrosyan et al., 2013; Levine, 2016), especially serotonergic axons. In NG2 null mice, spontaneous regrowth of serotonergic axons is impaired after SCI (de Castro et al., 2005). Moreover, NG2 cells stabilize degenerating axons at the lesion border, limiting axon "die-back" (McTigue et al., 2006; Yang et al., 2006; Busch et al., 2010). Thus, the enhanced NG2 cell response in/ around the contusion lesion in CX3CR1 $1^{-1-}$ mice could be responsible for the enhanced axonal density and sprouting that we observed (Figs. 3, 4).

Data in this report also show that, in remote lumbar spinal segments, inflammatory signaling is reduced in CX3CR $1^{-/-}$microglia and that these cells colocalize to regions where axon and synaptic plasticity are enhanced and motor neuron dendrite pathology is attenuated. Importantly, these changes occur on/ around motor neurons located within lumbar spinal segments containing the central pattern generator (CPG).

Within the CPG, serotonergic (5-HT) axons play a key role in activating and modulating lumbar motor circuitry (Grillner and Wallén, 1985; Jacobs and Fornal, 1997; Schmidt and Jordan, 2000; Murray et al., 2010; Gackière and Vinay, 2014; Leech et al., 2014). After SCI, 5-HT axons have a propensity to sprout and grow, bypassing the lesion and repopulating gray matter distal to the injury site. This vigorous growth response of 5-HT axons has been implicated in spontaneous recovery of locomotor function after SCI (Schmidt and Jordan, 2000; Murray et al., 2010; Gackière and Vinay, 2014; Leech et al., 2014). Despite this dynamic spontaneous growth, the overall magnitude of growth and lamina-specific distribution of 5-HT axons can be enhanced further using various genetic, pharmacologic or cell-based therapies (Müllner et al., 2008; Boato et al., 2010; Leech et al., 2014). These data indicate that optimal growth and guidance of 5-HT axons require the presence of specific molecular cues, some of which may be blocked or suppressed by CX3CR1-dependent signaling in microglia or macrophages. Indeed, data in the current report indicate that the density of $5-\mathrm{HT}^{+}$axons that grow into or around the lesion epicenter increased in mice deficient in CX3CR1 signaling. Also, the number of 5- $\mathrm{HT}^{+}$axons that spontaneously repopulate lumbar spinal cord gray matter increases in CX3CR1 $1^{-1-}$ mice, and the preferential growth of 5-HT axons around lumbar motor neurons is topographically appropriate. From these data, we can conclude that local guidance cues that regulate lamina-specific regrowth of 5-HT axons after SCI are inhibited by factors released downstream of CX3CR1 signaling in microglia.

Enhanced serotonergic axon plasticity and greater locomotor function in CX3CR1 ${ }^{-1-}$ mice could facilitate synaptic reorganization and reformation of appropriate sensorimotor networks below the level of injury. After SCI, dennervated neuronal circuitry tries to maintain function by modulating the axon sprouting and synaptic densities on newly formed circuits. Several reports have documented a progressive increase in synapse and axon density in segments distal to the lesion (Müllner et al., 2008; Tan et al., 2008; Bandaru et al., 2015). However, these newly formed circuits, unless "sculpted" or modulated by appropriate functional activity (e.g., rehabilitation), can promote aberrant neuronal functions, including pathological reflex control and neuronal exhaustion (Tan et al., 2012; Beauparlant et al., 2013; 


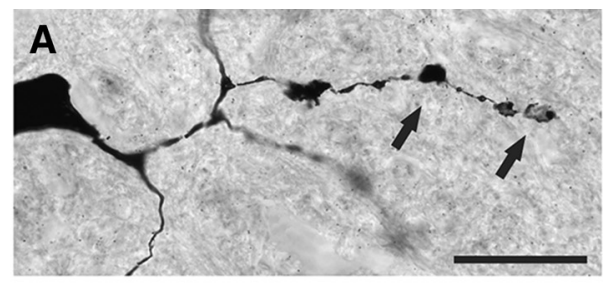

C

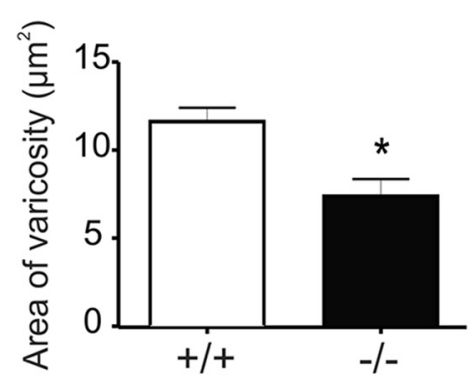

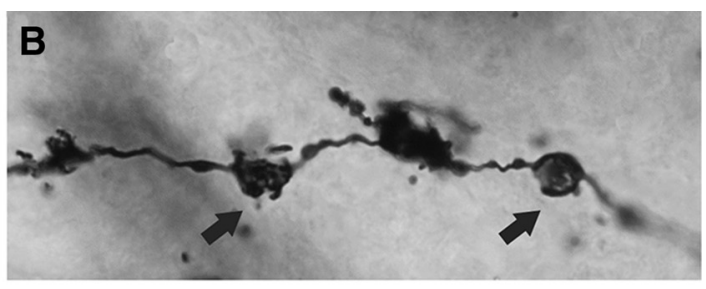

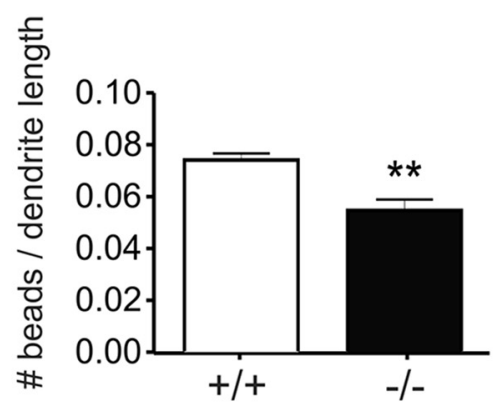

Control
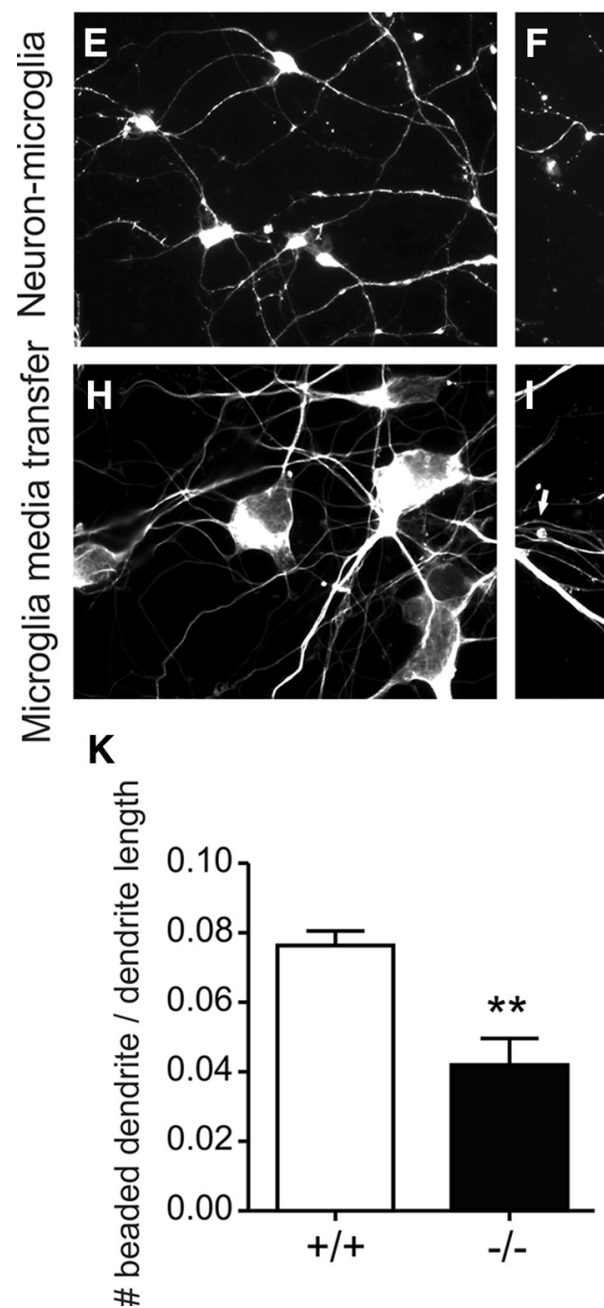

$\mathrm{CX} 3 \mathrm{CR} 1^{+/+}$
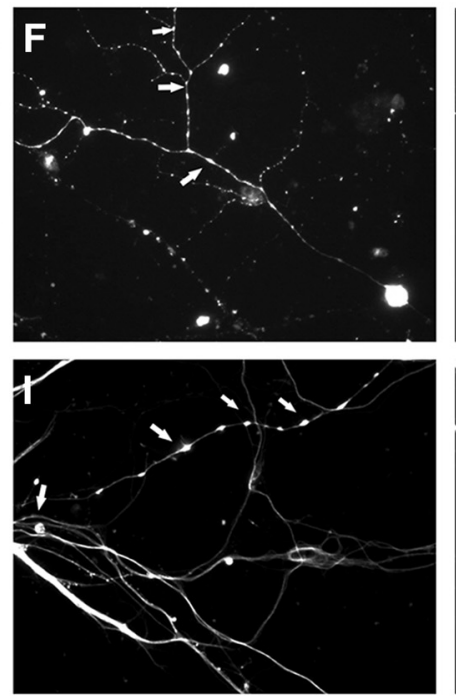

L
$\mathrm{CX} 3 \mathrm{CR} 1^{-1-}$
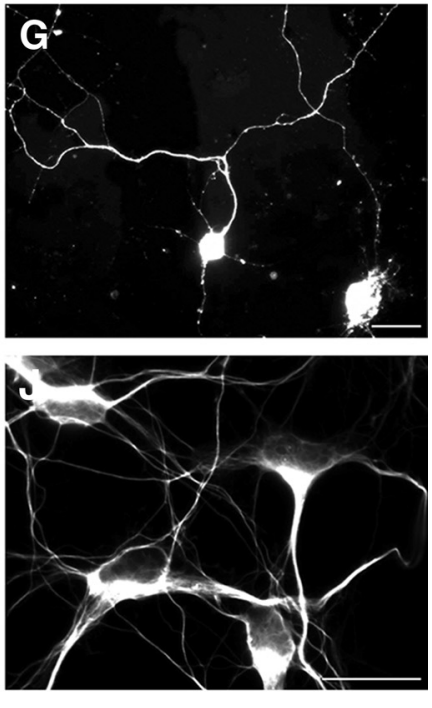

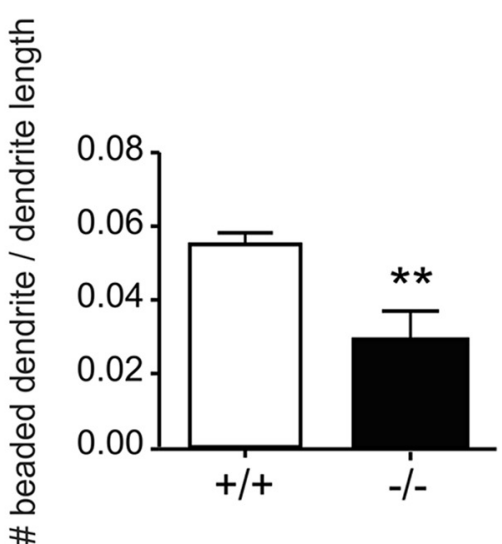

Figure 10. Microglia-dependent $C X 3 C R 1$ signaling causes dendrite pathology after $S C I$. $A, B$, Dendritic varicosities form on a subset of ventral horn lumbar motor neurons (lamina IX) after $S C I$. $\boldsymbol{C}, \boldsymbol{D}$, Greater numbers and larger varicosities are found on motor neurons in $\mathrm{CX} 3 \mathrm{CR} 1^{+/+}$compared with $\mathrm{CX} 3 \mathrm{CR} 1^{-/-}$mice. Representative images of neurons in neuron-microglia cocultures ( $\left.\boldsymbol{E}-\boldsymbol{G}\right)$ or neurons exposed to microglia-conditioned media $(\boldsymbol{H}-\boldsymbol{J}) . \boldsymbol{K}, \boldsymbol{L}, \mathrm{CX} 3 \mathrm{CR} 1^{-/-}$microglia cause less dendrite pathology than $\mathrm{CX} 3 \mathrm{CR} 1^{+/+}$microglia; the ratio of dendrite beads/axon length is decreased on neurons from both coculture $(\boldsymbol{K})$ and media transfer experiments $(\boldsymbol{L})$. Graphs are representative mean data from one of three independent replicate experiments. $\boldsymbol{C}, \boldsymbol{D}, n=5+/+$ and $n=4-/-$ mice/group. ${ }^{*} p<0.05$ (Student's unpaired two-tailed $t$ test). ${ }^{* *} p<0.01$ (Student's unpaired two-tailed $t$ test). $K$, $\boldsymbol{L}$, Student's unpaired two-tailed $t$ test. ${ }^{* *} p<0.01$. Scale bars: $A, 10 \mu \mathrm{m} ; G, J, 50 \mu \mathrm{m}$. Data are mean \pm SEM. 
Bandaru et al., 2015). Postinjury changes in the relative magnitude of excitatory and inhibitory synapses on lumbar motor neurons contribute to such functional deficits.

Serotonin regulates neuronal expression of KCC2, a potassiumchloride cotransporter that regulates intraneuronal chloride homeostasis and the maturation and function of excitatory and inhibitory neurotransmission (Chamma et al., 2012; Gackière and Vinay, 2015). After SCI, loss of serotonergic input is associated with an increase in excitatory synapses and a decrease in inhibitory synapses on lumbar motor neurons. Loss of inhibitory input increases motor neuron excitability. Regrowth or sprouting of serotonergic axons or pharmacological interventions that increase signaling via 5-HT receptors can restore KCC2 expression and normalize motor neuron excitability (Bos et al., 2013). In the present study, increased 5-HT fiber density in the lumbar spinal cord of CX3CR1 $1^{-1-}$ mice was associated with a significant increase in inhibitory synapses. Likewise, a notable increase of excitatory synapses was observed in the same group. These data could indicate that microglia, via CX3CR1-dependent signaling, normally inhibit postinjury remodeling of dendritic spines below the level of injury.

Published data show that dynamic remodeling of dendritic spines occurs throughout gray matter on neurons distal to the injury site (Bandaru et al., 2015). This compensatory response of neurons to denervation is enhanced in CX3CR1 $1^{-1-}$ microglia. In addition to improved recovery of locomotor function, it is possible that microglia CX3CR1-dependent changes in synapse formation also will affect other functional indices. For example, activating CX3CR1 can enhance synaptic strength and neurotransmission in nociceptive pathways (Clark et al., 2015). Thus, CX3CL1-CX3CR1 signaling may normally contribute to the onset and propagation of hyperreflexia and neuropathic pain after SCI (Tan et al., 2008; Bandaru et al., 2015).

Microglia may also regulate neuronal excitability by modulating sensitivity of neurons within CPG circuitry. Microglia associate with the axon hillock, specifically with the axon initial segment (Baalman et al., 2015) and CX3CL1-mediated activation of microglia (via CX3CR1) facilitates excitatory synaptic transmission (Clark et al., 2015). Thus, inhibiting CX3CR1 signaling in microglia could alter microglia-neuron cross talk to reverse the hyperexcitable state that is characteristic of neuronal networks in the CPG of SCI mammals.

Inflammatory signaling in microglia stimulates the synthesis and release of potentially dangerous cytokines and enzymes that can damage microtubules causing dendritic beading and synapse loss (Khairova et al., 2009; Maezawa and Jin, 2010; Hardingham et al., 2013; Yang et al., 2013). Thus, reduced inflammatory signaling in microglia could limit damage to axons and dendrites, yielding a circuitry that is better able to support recovery of function. Notably, in CX3CR1 ${ }^{-1-}$ mice, where inflammatory signaling is reduced in microglia, we found fewer dendritic varicosities on neurons (Fig. 9), and an identical phenotype was observed in vitro on neurons incubated with media conditioned by $\mathrm{CX} 3 \mathrm{CR} 1^{-/-}$microglia (Fig. 10).

Together, data in this report indicate that, in mice with deficient CX3CR1 signaling, the lesion milieu created by inflammatory microglia/macrophages is less toxic and more favorable to cell survival, repair, and plasticity. Future studies are needed to identify the complex molecular mechanisms that control CX3CR1dependent signaling and whether manipulating CX3CR1, either through use of blocking antibodies or small molecule inhibitors, can augment structural and functional plasticity alone or as an adjunct to facilitate rehabilitation.

\section{References}

Alvarez FJ, Villalba RM, Zerda R, Schneider SP (2004) Vesicular glutamate transporters in the spinal cord, with special reference to sensory primary afferent synapses. J Comp Neurol 472:257-280. CrossRef Medline

Baalman K, Marin MA, Ho TS, Godoy M, Cherian L, Robertson C, Rasband MN (2015) Axon initial segment-associated microglia. J Neurosci 35: 2283-2292. CrossRef Medline

Bakal C, Aach J, Church G, Perrimon N (2007) Quantitative morphological signatures define local signaling networks regulating cell morphology. Science 316:1753-1756. CrossRef Medline

Bandaru SP, Liu S, Waxman SG, Tan AM (2015) Dendritic spine dysgenesis contributes to hyperreflexia after spinal cord injury. J Neurophysiol 113: 1598-1615. CrossRef Medline

Bareyre FM, Kerschensteiner M, Raineteau O, Mettenleiter TC, Weinmann O, Schwab ME (2004) The injured spinal cord spontaneously forms a new intraspinal circuit in adult rats. Nat Neurosci 7:269-277. CrossRef Medline

Beauparlant J, van den Brand R, Barraud Q, Friedli L, Musienko P, Dietz V, Courtine G (2013) Undirected compensatory plasticity contributes to neuronal dysfunction after severe spinal cord injury. Brain 136:33473361. CrossRef Medline

Blackbeard J, O'Dea KP, Wallace VC, Segerdahl A, Pheby T, Takata M, Field MJ, Rice AS (2007) Quantification of the rat spinal microglial response to peripheral nerve injury as revealed by immunohistochemical image analysis and flow cytometry. J Neurosci Methods 164:207-217. CrossRef Medline

Boato F, Hendrix S, Huelsenbeck SC, Hofmann F, Grosse G, Djalali S, Klimaschewski L, Auer M, Just I, Ahnert-Hilger G, Höltje M (2010) C3 peptide enhances recovery from spinal cord injury by improved regenerative growth of descending fiber tracts. J Cell Sci 123:1652-1662. CrossRef Medline

Bos R, Sadlaoud K, Boulenguez P, Buttigieg D, Liabeuf S, Brocard C, Haase G, Bras H, Vinay L (2013) Activation of 5-HT2A receptors upregulates the function of the neuronal K-Cl cotransporter KCC2. Proc Natl Acad Sci U S A 110:348-353. CrossRef Medline

Busch SA, Horn KP, Silver DJ, Silver J (2009) Overcoming macrophagemediated axonal dieback following CNS injury. J Neurosci 29:9967-9976. CrossRef Medline

Busch SA, Horn KP, Cuascut FX, Hawthorne AL, Bai L, Miller RH, Silver J (2010) Adult NG2 ${ }^{+}$cells are permissive to neurite outgrowth and stabilize sensory axons during macrophage-induced axonal dieback after spinal cord injury. J Neurosci 30:255-265. CrossRef Medline

Cardona AE, Pioro EP, Sasse ME, Kostenko V, Cardona SM, Dijkstra IM, Huang D, Kidd G, Dombrowski S, Dutta R, Lee JC, Cook DN, Jung S, Lira SA, Littman DR, Ransohoff RM (2006) Control of microglial neurotoxicity by the fractalkine receptor. Nat Neurosci 9:917-924. CrossRef Medline

Chamma I, Chevy Q, Poncer JC, Lévi S (2012) Role of the neuronal K-Cl co-transporter KCC2 in inhibitory and excitatory neurotransmission. Front Cell Neurosci 6:5. Medline

Ciranna L (2006) Serotonin as a modulator of glutamate- and GABAmediated neurotransmission: implications in physiological functions and in pathology. Curr Neuropharmacol 4:101-114. CrossRef Medline

Clark AK, Gruber-Schoffnegger D, Drdla-Schutting R, Gerhold KJ, Malcangio M, Sandkühler J (2015) Selective activation of microglia facilitates synaptic strength. J Neurosci 35:4552-4570. CrossRef Medline

Cohen M, Matcovitch O, David E, Barnett-Itzhaki Z, Keren-Shaul H, Blecher-Gonen R, Jaitin DA, Sica A, Amit I, Schwartz M (2014) Chronic exposure to TGF $\beta 1$ regulates myeloid cell inflammatory response in an IRF7-dependent manner. EMBO J 33:2906-2921. CrossRef Medline

Courtine G, Song B, Roy RR, Zhong H, Herrmann JE, Ao Y, Qi J, Edgerton VR, Sofroniew MV (2008) Recovery of supraspinal control of stepping via indirect propriospinal relay connections after spinal cord injury. Nat Med 14:69-74. CrossRef Medline

Cowley KC, Schmidt BJ (1997) Regional distribution of the locomotor pattern-generating network in the neonatal rat spinal cord. J Neurophysiol 77:247-259. Medline

Davalos D, Grutzendler J, Yang G, Kim JV, Zuo Y, Jung S, Littman DR, Dustin ML, Gan WB (2005) ATP mediates rapid microglial response to local brain injury in vivo. Nat Neurosci 8:752-758. CrossRef Medline 
David S, Kroner A (2011) Repertoire of microglial and macrophage responses after spinal cord injury. Nat Rev Neurosci 12:388-399. CrossRef Medline

de Castro R Jr, Tajrishi R, Claros J, Stallcup WB (2005) Differential responses of spinal axons to transection: influence of the NG2 proteoglycan. Exp Neurol 192:299-309. CrossRef Medline

Detloff MR, Fisher LC, McGaughy V, Longbrake EE, Popovich PG, Basso DM (2008) Remote activation of microglia and pro-inflammatory cytokines predict the onset and severity of below-level neuropathic pain after spinal cord injury in rats. Exp Neurol 212:337-347. CrossRef Medline

Diemel LT, Jackson SJ, Cuzner ML (2003) Role for TGF-beta1, FGF-2 and PDGF-AA in a myelination of CNS aggregate cultures enriched with macrophages. J Neurosci Res 74:858-867. CrossRef Medline

Donnelly DJ, Gensel JC, Ankeny DP, van Rooijen N, Popovich PG (2009) An efficient and reproducible method for quantifying macrophages in different experimental models of central nervous system pathology. J Neurosci Methods 181:36-44. CrossRef Medline

Donnelly DJ, Longbrake EE, Shawler TM, Kigerl KA, Lai W, Tovar CA, Ransohoff RM, Popovich PG (2011) Deficient CX3CR1 signaling promotes recovery after mouse spinal cord injury by limiting the recruitment and activation of Ly6Clo/iNOS ${ }^{+}$macrophages. J Neurosci 31:9910-9922. CrossRef Medline

Freria CM, Velloso LA, Oliveira AL (2012) Opposing effects of Toll-like receptors 2 and 4 on synaptic stability in the spinal cord after peripheral nerve injury. J Neuroinflammation 9:240. CrossRef Medline

Frost EE, Nielsen JA, Le TQ, Armstrong RC (2003) PDGF and FGF2 regulate oligodendrocyte progenitor responses to demyelination. J Neurobiol 54:457-472. CrossRef Medline

Gackière F, Vinay L (2014) Serotonergic modulation of post-synaptic inhibition and locomotor alternating pattern in the spinal cord. Front Neural Circuits 8:102. CrossRef Medline

Gackière F, Vinay L (2015) Contribution of the potassium-chloride cotransporter KCC2 to the strength of inhibition in the neonatal rodent spinal cord in vitro. J Neurosci 35:5307-5316. CrossRef Medline

Gensel JC, Nakamura S, Guan Z, van Rooijen N, Ankeny DP, Popovich PG (2009) Macrophages promote axon regeneration with concurrent neurotoxicity. J Neurosci 29:3956-3968. CrossRef Medline

Gensel JC, Wang Y, Guan Z, Beckwith KA, Braun KJ, Wei P, McTigue DM, Popovich PG (2015) Toll-like receptors and dectin-1, a C-type lectin receptor, trigger divergent functions in CNS macrophages. J Neurosci 35:9966-9976. CrossRef Medline

Grau JW, Huie JR, Lee KH, Hoy KC, Huang YJ, Turtle JD, Strain MM, Baumbauer KM, Miranda RM, Hook MA, Ferguson AR, Garraway SM (2014) Metaplasticity and behavior: how training and inflammation affect plastic potential within the spinal cord and recovery after injury. Front Neural Circuits 8:100. CrossRef Medline

Greenwood SM, Connolly CN (2007) Dendritic and mitochondrial changes during glutamate excitotoxicity. Neuropharmacology 53:891-898. CrossRef Medline

Greenwood SM, Mizielinska SM, Frenguelli BG, Harvey J, Connolly CN (2007) Mitochondrial dysfunction and dendritic beading during neuronal toxicity. J Biol Chem 282:26235-26244. CrossRef Medline

Grillner S, Wallén P (1985) Central pattern generators for locomotion, with special reference to vertebrates. Annu Rev Neurosci 8:233-261. CrossRef Medline

Gutierrez-Mecinas M, Kuehn ED, Abraira VE, Polgár E, Watanabe M, Todd AJ (2016) Immunostaining for Homer reveals the majority of excitatory synapses in laminae I-III of the mouse spinal dorsal horn. Neuroscience 329:171-181. CrossRef Medline

Hains BC, Waxman SG (2006) Activated microglia contribute to the maintenance of chronic pain after spinal cord injury. J Neurosci 26:43084317. CrossRef Medline

Hansen CN, Fisher LC, Deibert RJ, Jakeman LB, Zhang H, Noble-Haeusslein L, White S, Basso DM (2013) Elevated MMP-9 in the lumbar cord early after thoracic spinal cord injury impedes motor relearning in mice. J Neurosci 33:13101-13111. CrossRef Medline

Hardingham N, Dachtler J, Fox K (2013) The role of nitric oxide in presynaptic plasticity and homeostasis. Front Cell Neurosci 7:190. CrossRef Medline

Harkema S, Gerasimenko Y, Hodes J, Burdick J, Angeli C, Chen Y, Ferreira C, Willhite A, Rejc E, Grossman RG, Edgerton VR (2011) Effect of epidural stimulation of the lumbosacral spinal cord on voluntary movement, standing, and assisted stepping after motor complete paraplegia: a case study. Lancet 377:1938-1947. CrossRef Medline

Hawthorne AL, Hu H, Kundu B, Steinmetz MP, Wylie CJ, Deneris ES, Silver J (2011) The unusual response of serotonergic neurons after CNS injury: lack of axonal dieback and enhanced sprouting within the inhibitory environment of the glial scar. J Neurosci 31:5605-5616. CrossRef Medline

Hayashi Y, Majewska AK (2005) Dendritic spine geometry: functional implication and regulation. Neuron 46:529-532. CrossRef Medline

Herlaar E, Brown Z (1999) p38 MAPK signalling cascades in inflammatory disease. Mol Med Today 5:439-447. CrossRef Medline

Hines DJ, Hines RM, Mulligan SJ, Macvicar BA (2009) Microglia processes block the spread of damage in the brain and require functional chloride channels. Glia 57:1610-1618. CrossRef Medline

Horn KP, Busch SA, Hawthorne AL, van Rooijen N, Silver J (2008) Another barrier to regeneration in the CNS: activated macrophages induce extensive retraction of dystrophic axons through direct physical interactions. J Neurosci 28:9330-9341. CrossRef Medline

Hoshiko M, Arnoux I, Avignone E, Yamamoto N, Audinat E (2012) Deficiency of the microglial receptor CX3CR1 impairs postnatal functional development of thalamocortical synapses in the barrel cortex. J Neurosci 32:15106-15111. CrossRef Medline

Ikegaya Y, Kim JA, Baba M, Iwatsubo T, Nishiyama N, Matsuki N (2001) Rapid and reversible changes in dendrite morphology and synaptic efficacy following NMDA receptor activation: implication for a cellular defense against excitotoxicity. J Cell Sci 114:4083-4093. Medline

Jacobs BL, Fornal CA (1997) Serotonin and motor activity. Curr Opin Neurobiol 7:820-825. CrossRef Medline

Jin Y, Dougherty SE, Wood K, Sun L, Cudmore RH, Abdalla A, Kannan G, Pletnikov M, Hashemi P, Linden DJ (2016) Regrowth of serotonin axons in the adult mouse brain following injury. Neuron 91:748-762. CrossRef Medline

Jung S, Aliberti J, Graemmel P, Sunshine MJ, Kreutzberg GW, Sher A, Littman DR (2000) Analysis of fractalkine receptor CX(3)CR1 function by targeted deletion and green fluorescent protein reporter gene insertion. Mol Cell Biol 20:4106-4114. CrossRef Medline

Khairova RA, Machado-Vieira R, Du J, Manji HK (2009) A potential role for pro-inflammatory cytokines in regulating synaptic plasticity in major depressive disorder. Int J Neuropsychopharmacol 12:561-578. CrossRef Medline

Kigerl KA, McGaughy VM, Popovich PG (2006) Comparative analysis of lesion development and intraspinal inflammation in four strains of mice following spinal contusion injury. J Comp Neurol 494:578-594. CrossRef Medline

Kigerl KA, Gensel JC, Ankeny DP, Alexander JK, Donnelly DJ, Popovich PG (2009) Identification of two distinct macrophage subsets with divergent effects causing either neurotoxicity or regeneration in the injured mouse spinal cord. J Neurosci 29:13435-13444. CrossRef Medline

Kroner A, Greenhalgh AD, Zarruk JG, Passos Dos Santos R, Gaestel M, David S (2014) TNF and increased intracellular iron alter macrophage polarization to a detrimental M1 phenotype in the injured spinal cord. Neuron 83:1098-1116. CrossRef Medline

Landry M, Bouali-Benazzouz R, El Mestikawy S, Ravassard P, Nagy F (2004) Expression of vesicular glutamate transporters in rat lumbar spinal cord, with a note on dorsal root ganglia. J Comp Neurol 468:380-394. CrossRef Medline

Leech KA, Kinnaird CR, Hornby TG (2014) Effects of serotonergic medications on locomotor performance in humans with incomplete spinal cord injury. J Neurotrauma 31:1334-1342. CrossRef Medline

Levine AJ, Hinckley CA, Hilde KL, Driscoll SP, Poon TH, Montgomery JM, Pfaff SL (2014) Identification of a cellular node for motor control pathways. Nat Neurosci 17:586-593. CrossRef Medline

Levine J (2016) The reactions and role of NG2 glia in spinal cord injury. Brain Res 1638:199-208. CrossRef Medline

Liu H, Shubayev VI (2011) Matrix metalloproteinase-9 controls proliferation of $\mathrm{NG}^{+}$progenitor cells immediately after spinal cord injury. Exp Neurol 231:236-246. CrossRef Medline

Longbrake EE, Lai W, Ankeny DP, Popovich PG (2007) Characterization and modeling of monocyte-derived macrophages after spinal cord injury. J Neurochem 102:1083-1094. CrossRef Medline

Lu H, Huang D, Saederup N, Charo IF, Ransohoff RM, Zhou L (2011) Macrophages recruited via CCR2 produce insulin-like growth factor-1 to repair acute skeletal muscle injury. FASEB J 25:358-369. CrossRef Medline 
Lytle JM, Vicini S, Wrathall JR (2006) Phenotypic changes in NG2 ${ }^{+}$cells after spinal cord injury. J Neurotrauma 23:1726-1738. CrossRef Medline

Lytle JM, Chittajallu R, Wrathall JR, Gallo V (2009) NG2 cell response in the CNP-EGFP mouse after contusive spinal cord injury. Glia 57:270-285. CrossRef Medline

Maezawa I, Jin LW (2010) Rett syndrome microglia damage dendrites and synapses by the elevated release of glutamate. J Neurosci 30:5346-5356. CrossRef Medline

McTigue DM, Horner PJ, Stokes BT, Gage FH (1998) Neurotrophin-3 and brain-derived neurotrophic factor induce oligodendrocyte proliferation and myelination of regenerating axons in the contused adult rat spinal cord. J Neurosci 18:5354-5365. Medline

McTigue DM, Popovich PG, Morgan TE, Stokes BT (2000) Localization of transforming growth factor-betal and receptor mRNA after experimental spinal cord injury. Exp Neurol 163:220-230. CrossRef Medline

McTigue DM, Wei P, Stokes BT (2001) Proliferation of NG2-positive cells and altered oligodendrocyte numbers in the contused rat spinal cord. J Neurosci 21:3392-3400. Medline

McTigue DM, Tripathi R, Wei P (2006) NG2 colocalizes with axons and is expressed by a mixed cell population in spinal cord lesions. J Neuropathol Exp Neurol 65:406-420. CrossRef Medline

McWhorter FY, Wang T, Nguyen P, Chung T, Liu WF (2013) Modulation of macrophage phenotype by cell shape. Proc Natl Acad Sci U S A 110: 17253-17258. CrossRef Medline

Miron VE, Boyd A, Zhao JW, Yuen TJ, Ruckh JM, Shadrach JL, van Wijngaarden P, Wagers AJ, Williams A, Franklin RJ, ffrench-Constant C (2013) M2 microglia and macrophages drive oligodendrocyte differentiation during CNS remyelination. Nat Neurosci 16:1211-1218. CrossRef Medline

Müllner A, Gonzenbach RR, Weinmann O, Schnell L, Liebscher T, Schwab ME (2008) Lamina-specific restoration of serotonergic projections after Nogo-A antibody treatment of spinal cord injury in rats. Eur J Neurosci 27:326-333. CrossRef Medline

Murray KC, Nakae A, Stephens MJ, Rank M, D’Amico J, Harvey PJ, Li X, Harris RL, Ballou EW, Anelli R, Heckman CJ, Mashimo T, Vavrek R, Sanelli L, Gorassini MA, Bennett DJ, Fouad K (2010) Recovery of motoneuron and locomotor function after spinal cord injury depends on constitutive activity in 5-HT2C receptors. Nat Med 16:694-700. CrossRef Medline

Oliveira AL, Hydling F, Olsson E, Shi T, Edwards RH, Fujiyama F, Kaneko T, Hökfelt T, Cullheim S, Meister B (2003) Cellular localization of three vesicular glutamate transporter mRNAs and proteins in rat spinal cord and dorsal root ganglia. Synapse 50:117-129. CrossRef Medline

Paolicelli RC, Bolasco G, Pagani F, Maggi L, Scianni M, Panzanelli P, Giustetto M, Ferreira TA, Guiducci E, Dumas L, Ragozzino D, Gross CT (2011) Synaptic pruning by microglia is necessary for normal brain development. Science 333:1456-1458. CrossRef Medline

Persson S, Boulland JL, Aspling M, Larsson M, Fremeau RT Jr, Edwards RH, Storm-Mathisen J, Chaudhry FA, Broman J (2006) Distribution of vesicular glutamate transporters 1 and 2 in the rat spinal cord, with a note on the spinocervical tract. J Comp Neurol 497:683-701. CrossRef Medline

Petrosyan HA, Hunanyan AS, Alessi V, Schnell L, Levine J, Arvanian VL (2013) Neutralization of inhibitory molecule NG2 improves synaptic transmission, retrograde transport, and locomotor function after spinal cord injury in adult rats. J Neurosci 33:4032-4043. CrossRef Medline

Pont-Lezica L, Beumer W, Colasse S, Drexhage H, Versnel M, Bessis A (2014) Microglia shape corpus callosum axon tract fasciculation: functional impact of prenatal inflammation. Eur J Neurosci 39:1551-1557. CrossRef Medline

Popovich PG, Hickey WF (2001) Bone marrow chimeric rats reveal the unique distribution of resident and recruited macrophages in the contused rat spinal cord. J Neuropathol Exp Neurol 60:676-685. CrossRef Medline

Popovich PG, Longbrake EE (2008) Can the immune system be harnessed to repair the CNS? Nat Rev Neurosci 9:481-493. CrossRef Medline

Popovich PG, Wei P, Stokes BT (1997) Cellular inflammatory response after spinal cord injury in Sprague-Dawley and Lewis rats. J Comp Neurol 377:443-464. CrossRef Medline

Popovich PG, Guan Z, Wei P, Huitinga I, van Rooijen N, Stokes BT (1999) Depletion of hematogenous macrophages promotes partial hindlimb recovery and neuroanatomical repair after experimental spinal cord injury. Exp Neurol 158:351-365. CrossRef Medline
Risher WC, Ustunkaya T, Singh Alvarado J, Eroglu C (2014) Rapid Golgi analysis method for efficient and unbiased classification of dendritic spines. PLoS One 9:e107591. CrossRef Medline

Rogers JT, Morganti JM, Bachstetter AD, Hudson CE, Peters MM, Grimmig BA, Weeber EJ, Bickford PC, Gemma C (2011) CX3CR1 deficiency leads to impairment of hippocampal cognitive function and synaptic plasticity. J Neurosci 31:16241-16250. CrossRef Medline

Rosenzweig ES, Courtine G, Jindrich DL, Brock JH, Ferguson AR, Strand SC, Nout YS, Roy RR, Miller DM, Beattie MS, Havton LA, Bresnahan JC, Edgerton VR, Tuszynski MH (2010) Extensive spontaneous plasticity of corticospinal projections after primate spinal cord injury. Nat Neurosci 13:1505-1510. CrossRef Medline

Rossignol S, Barrière G, Alluin O, Frigon A (2009) Re-expression of locomotor function after partial spinal cord injury. Physiology (Bethesda) 24:127-139. CrossRef Medline

Saklatvala J (2004) The p38 MAP kinase pathway as a therapeutic target in inflammatory disease. Curr Opin Pharmacol 4:372-377. CrossRef Medline

Saruhashi Y, Young W, Perkins R (1996) The recovery of 5-HT immunoreactivity in lumbosacral spinal cord and locomotor function after thoracic hemisection. Exp Neurol 139:203-213. CrossRef Medline

Saura J, Tusell JM, Serratosa J (2003) High-yield isolation of murine microglia by mild trypsinization. Glia 44:183-189. CrossRef Medline

Schmidt BJ, Jordan LM (2000) The role of serotonin in reflex modulation and locomotor rhythm production in the mammalian spinal cord. Brain Res Bull 53:689-710. CrossRef Medline

Schmittgen TD, Livak KJ (2008) Analyzing real-time PCR data by the comparative $\mathrm{C}(\mathrm{T})$ method. Nat Protoc 3:1101-1108. CrossRef Medline

Shin HY, Kim H, Kwon MJ, Hwang DH, Lee K, Kim BG (2014) Molecular and cellular changes in the lumbar spinal cord following thoracic injury: regulation by treadmill locomotor training. PLoS One 9:e88215. CrossRef Medline

Squarzoni P, Oller G, Hoeffel G, Pont-Lezica L, Rostaing P, Low D, Bessis A, Ginhoux F, Garel S (2014) Microglia modulate wiring of the embryonic forebrain. Cell Rep 8:1271-1279. CrossRef Medline

Suh HS, Zhao ML, Derico L, Choi N, Lee SC (2013) Insulin-like growth factor 1 and 2 (IGF1, IGF2) expression in human microglia: differential regulation by inflammatory mediators. J Neuroinflammation 10:37. CrossRef Medline

Takeoka A, Kubasak MD, Zhong H, Roy RR, Phelps PE (2009) Serotonergic innervation of the caudal spinal stump in rats after complete spinal transection: effect of olfactory ensheathing glia. J Comp Neurol 515:664-676. CrossRef Medline

Tan AM, Zhang W, Levine JM (2005) NG2: a component of the glial scar that inhibits axon growth. J Anat 207:717-725. CrossRef Medline

Tan AM, Colletti M, Rorai AT, Skene JH, Levine JM (2006) Antibodies against the NG2 proteoglycan promote the regeneration of sensory axons within the dorsal columns of the spinal cord. J Neurosci 26:4729-4739. CrossRef Medline

Tan AM, Stamboulian S, Chang YW, Zhao P, Hains AB, Waxman SG, Hains BC (2008) Neuropathic pain memory is maintained by Racl-regulated dendritic spine remodeling after spinal cord injury. J Neurosci 28:1317313183. CrossRef Medline

Tan AM, Chakrabarty S, Kimura H, Martin JH (2012) Selective corticospinal tract injury in the rat induces primary afferent fiber sprouting in the spinal cord and hyperreflexia. J Neurosci 32:12896-12908. CrossRef Medline

Tretter V, Mukherjee J, Maric HM, Schindelin H, Sieghart W, Moss SJ (2012) Gephyrin, the enigmatic organizer at GABAergic synapses. Front Cell Neurosci 6:23. CrossRef Medline

Tripathi R, McTigue DM (2007) Prominent oligodendrocyte genesis along the border of spinal contusion lesions. Glia 55:698-711. CrossRef Medline

Wang X, Cao K, Sun X, Chen Y, Duan Z, Sun L, Guo L, Bai P, Sun D, Fan J, He X, Young W, Ren Y (2015) Macrophages in spinal cord injury: phenotypic and functional change from exposure to myelin debris. Glia 63:635651. CrossRef Medline

Wennström M, Janelidze S, Bay-Richter C, Minthon L, Brundin L (2014) Pro-inflammatory cytokines reduce the proliferation of NG2 cells and increase shedding of NG2 in vivo and in vitro. PLoS One 9:e109387. CrossRef Medline 
Wilms H, Hartmann D, Sievers J (1997) Ramification of microglia, monocytes and macrophages in vitro: influences of various epithelial and mesenchymal cells and their conditioned media. Cell Tissue Res 287:447-458. CrossRef Medline

Wu J, Yoo S, Wilcock D, Lytle JM, Leung PY, Colton CA, Wrathall JR (2010) Interaction of $\mathrm{NG2}(+)$ glial progenitors and microglia/macrophages from the injured spinal cord. Glia 58:410-422. CrossRef Medline

Yang G, Parkhurst CN, Hayes S, Gan WB (2013) Peripheral elevation of TNF- $\alpha$ leads to early synaptic abnormalities in the mouse somatosensory cortex in experimental autoimmune encephalomyelitis. Proc Natl Acad Sci U S A 110:10306-10311. CrossRef Medline

Yang Z, Suzuki R, Daniels SB, Brunquell CB, Sala CJ, Nishiyama A (2006)
NG2 glial cells provide a favorable substrate for growing axons. J Neurosci 26:3829-3839. CrossRef Medline

Yuste R, Bonhoeffer T (2001) Morphological changes in dendritic spines associated with long-term synaptic plasticity. Annu Rev Neurosci 24: 1071-1089. CrossRef Medline

Zhao P, Waxman SG, Hains BC (2007) Modulation of thalamic nociceptive processing after spinal cord injury through remote activation of thalamic microglia by cysteine cysteine chemokine ligand 21. J Neurosci 27:88938902. CrossRef Medline

Zhou L, Shine HD (2003) Neurotrophic factors expressed in both cortex and spinal cord induce axonal plasticity after spinal cord injury. J Neurosci Res 74:221-226. CrossRef Medline 